\title{
On the Albian occurrence of Armigatus (Teleostei, Clupeomorpha) in America, a new species from the Tlayúa Lagerstätte, Mexico
}

\author{
Jesús Alvarado-Ortega, Bruno Andrés Than-Marchese, \\ and María del Pilar Melgarejo-Damián
}

\begin{abstract}
A new fossil herring species is named in this work as Armigatus carrenoae, based on specimens from the marine Albian deposits of the Tlayúa Formation, near Tepexi de Rodríguez, Puebla, Central Mexico. The new species shows the most distinctive feature of the superorder Clupeomorpha, the abdominal scute series, as well as the order Ellimmichthyiformes, the posteriormost predorsal scutes laterally expanded, the mesoparietal condition of the skull, and the presence of the beryciform foramen in the anterior ceratohyal. Also, this species shares the diagnostic features of the genus Armigatus, the parasphenoid has an osteoglossid-like tooth patch and the predorsal scutes series is incomplete. Additionally, in this species, the posteriormost predorsal scutes exhibit a posterior spine, a character not observed before in Armigatus. This discovery is highly significant because it represents the oldest member of Armigatus, as well as the first record of the genus in America and reveals its unsuspected wide distribution during the late Early to Late Cretaceous throughout the Tethys Sea deposits, from America to the Middle East.
\end{abstract}

Jesús Alvarado-Ortega. Instituto de Geología, Universidad Nacional Autónoma de México, Circuito de la Investigación S/N, Ciudad Universitaria, Delegación Coyoacán, Ciudad de México, 04510 México.

alvarado@geologia.unam.mx

Bruno Andrés Than-Marchese. Doctorado en Ciencias en Biodiversidad y Conservación de Ecosistemas Tropicales, Instituto de Ciencias Biológicas, Universidad de Ciencias y Artes de Chiapas, Libramiento Norte No. 1150, Colonia Lajas Maciel, Tuxtla Gutiérrez, Chiapas, C.P. 29039, México;

bruthmar@gmail.com

María del Pilar Melgarejo-Damián. Posgrado en Ciencias Biológicas, Universidad Nacional Autónoma de México, Circuito de la Investigación S/N, Ciudad Universitaria, Delegación Coyoacán, Ciudad de México, 04510 México. pilar_melgarejo@yahoo.com

http://zoobank.org/2D402356-E969-45A0-808A-989F3FD38B0C

Alvarado-Ortega, Jesús, Than-Marchese, Bruno Andrés, and Melgarejo-Damián, María del Pilar. 2020. On the Albian occurrence of Armigatus (Teleostei, Clupeomorpha) in America, a new species from the Tlayúa Lagerstätte, Mexico. Palaeontologia Electronica, 23(3):a52. https://doi.org/10.26879/1107

palaeo-electronica.org/content/2020/3211-albian-armigatus-in-america

Copyright: November 2020 Paleontological Society.

This is an open access article distributed under the terms of Attribution-NonCommercial-ShareAlike 4.0 International (CC BY-NC-SA 4.0), which permits users to copy and redistribute the material in any medium or format, provided it is not used for commercial purposes and the original author and source are credited, with indications if any changes are made.

creativecommons.org/licenses/by-nc-sa/4.0/ 
Keywords: Armigatus; new species; Ellimmichthyifomes; Albian; Tlayúa; Mexico

Submission: 28 June 2020. Acceptance: 8 November 2020.

\section{INTRODUCTION}

The genus Armigatus Grande, 1982, is a Late Cretaceous clupeomorph fish, well known by many specimens recovered from the epicontinental shallow marine deposits into the western realm of the Tethys Sea, distributed along the paleocontinents of Laurentia and Gondwana, and now exposed in Europe, Middle East, and Northern Africa. This genus was established to include the species Armigatus brevissimus (Blainville, 1818) from the Cenomanian fossiliferous deposits at Heckel and Hajula, Lebanon (Figure 1), originally named as Clupea brevissimus and later as Diplomystus brevissimus. Up to now, four additional species have been described and included in this genus. Forey et al. (2003) described a couple of these as A. alticorpus and $A$. namourensis, from in the Cenomanian deposits of Namoura, Lebanon. Recently, Vernygora and Murray (2021) described new specimens of $A$. alticorpus from Heckel. The African species, A. oligodentatus Vernygora and Murray, 2016, is based on specimens from Cenomanian/Turonian sediments at Agoult, Morocco. And finally, the youngest species, A. dalmaticus Murray et al.,
2016, is from possible Campanian deposits exposed in Dalmatia, Croatia, European Balkan region.

The relationships and monophyly of Armigatus are somewhat problematic. In his comprehensive review of the superorder Clupeomorpha, Grande $(1982,1985)$ allocated these fishes into two Divisions. Today, his Division 1 is invalid because its single member, Erichalcis arcata Forey, 1975, from the Albian marine deposits of the Loon River Formation, Northwest Territories, Canada, is a composite species that involves a salmoniform (Hermus and Wilson, 2001; Hermus et al., 2004) as well as a primitive clupeomorph fish recently named as Foreyclupea loonensis Vernygora et al., 2016. Otherwise, Grande's Division 2 includes all the remaining clupeomorph species gathered into the orders Clupeiformes and Ellimmichthyiformes plus Armigatus, an incertae sedis genus and a putative close relative of ellimmichthyiforms (Grande, 1985). Some recent phylogenetic studies show Armigatus just as a close relative of the Ellimmichthyiformes (Taverne, 1997; Chang and Maisey, 2003; Zaragüeta-Bagils, 2004; and

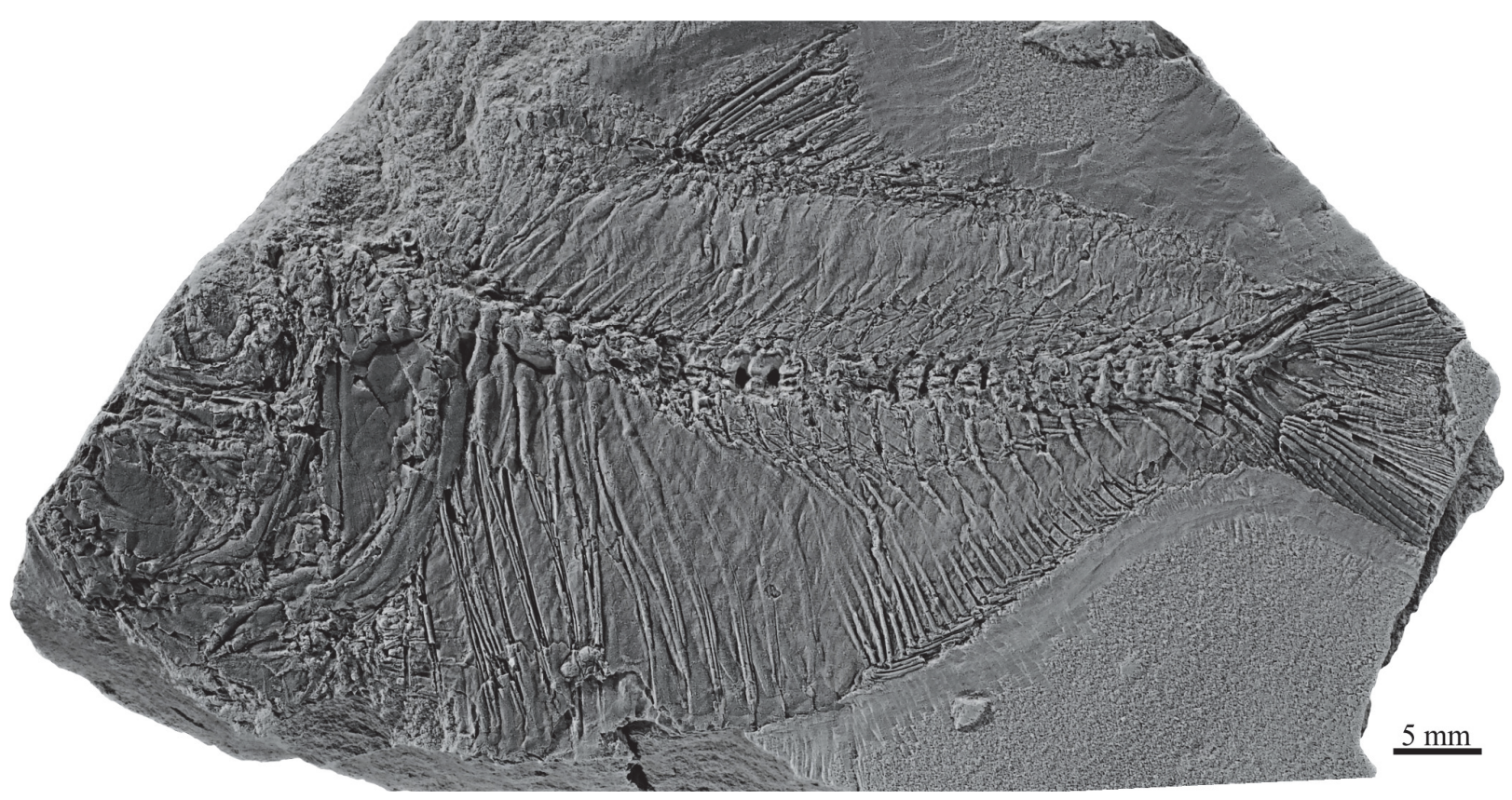

FIGURE 1. Specimen IGM 11532, Armigatus brevissimus from the Cenomanian shallow marine deposits of Hekel, Lebanon, coated with magnesium smoke. 


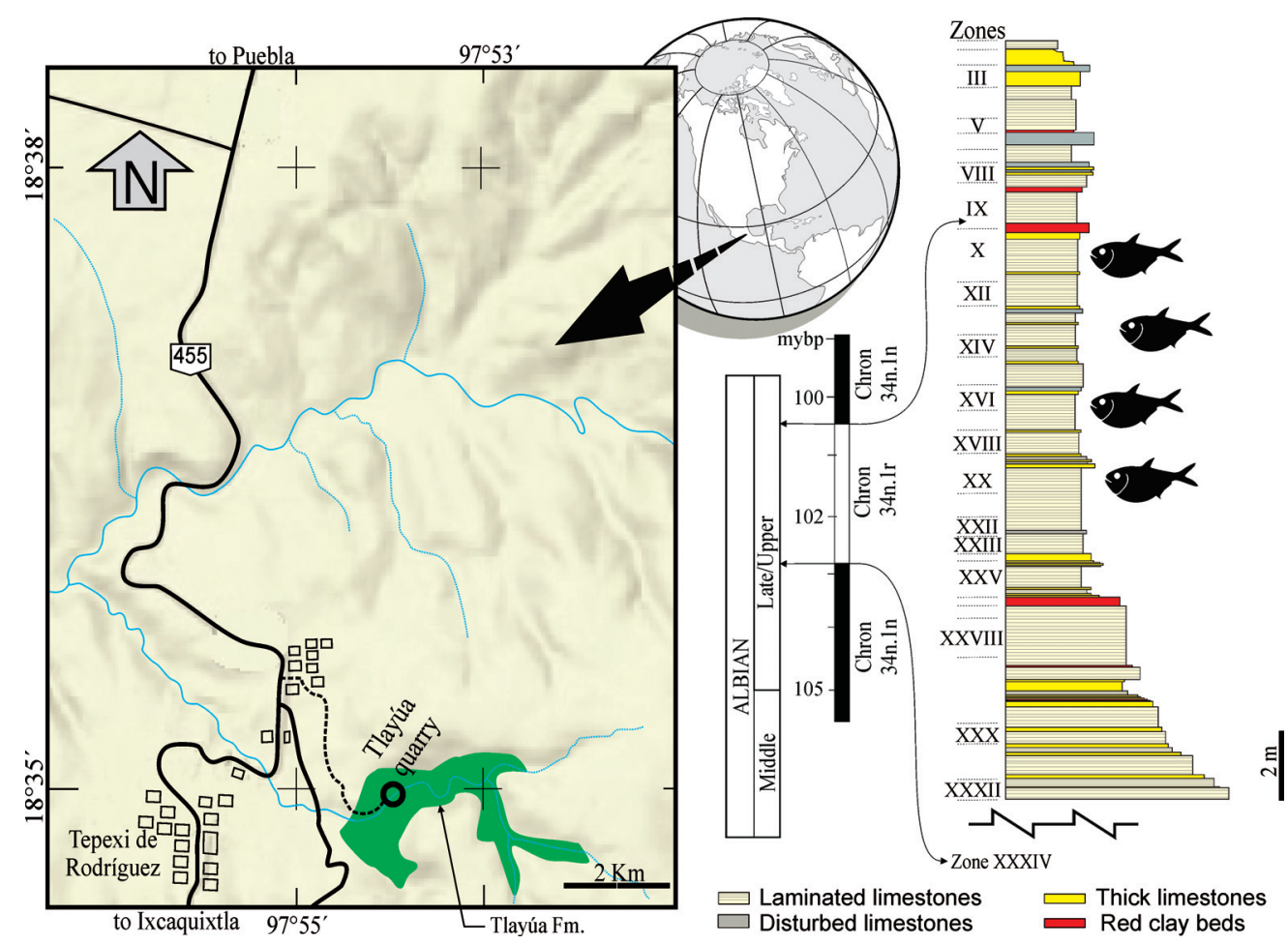

FIGURE 2. Map of the Tlayúa quarry near Tepexi de Rodríguez, Puebla, central Mexico, and the stratigraphical column of the upper part of this site, including the magnetostratigraphy correspondence with the middle-late Albian age, and the distribution of fossils studied in this work (modified from Kashiyama et al., 2004, figure 3; Alvarado-Ortega 2005, figure 2.4; Benammi et al., 2006, figure 5).

Alvarado-Ortega et al., 2008) while other studies point to the inclusion of Armigatus within this order (Forey, 2004; Hay et al., 2007; Murray and Wilson, 2013; Vernygora et al., 2016; Figueiredo and Ribeiro, 2016, 2017; Marramà and Carnevale, 2017; Marramà et al., 2019). Moreover, Vernygora and Murray (2016) and Murray et al. (2016) claim that Armigatus is monophyletic; however, Figueiredo and Ribeiro (2016) and Boukhalfa et al. (2019) challenge such idea and concluded that Armigatus is an unnatural clade.

Numerous clupeomorphs have been recovered from Tlayúa quarry. Among these, Applegate (1996) reported the presence of ellimmichthyiforms that he vaguely referred as "Diplomystus-like". The occurrence of Diplomystus Cope, 1877, in Tlayúa is not confirmed but other clupeomorphs from this site have been formally studied. Up to now, these fishes represent the species Ranulfoichthys dorsonudum Alvarado-Ortega, 2014, and Paraclupea seilacheri Alvarado-Ortega and Melgarejo-Damián, 2017. The probable presence of Armigatus in Tlayúa was first pointed out by Melgarejo-Damián and Alvarado-Ortega $(2009,2010,2013)$ and Melgarejo-Damián (2011), based on a multivariate quantitative analysis of the double armored herring specimens from this quarry. Therefore, the present work aims to provide an accurate morphological description of such fossil fishes, to name a new species of the genus Armigatus, and to discuss its relationships.

The Tlayúa quarry is an emblematic Mexican Konservat-Lagerstätte site near the Tepexi de Rodríguez town of Puebla, Central Mexico (Applegate et al., 1982, 2006; Martill, 1989; AlvaradoOrtega, 1999; Alvarado-Ortega et al., 2006, 2007; among others) (Figure 2). In the beginning, this site, exposed in the northwestern side of the Tlayúa Ravine, was exploited only with commercial purposes to get reddish flagstones from a sequence of laminated parallel limestones (Applegate and Espinosa-Arrubarrena, 1982). PantojaAlor (1992) suggested the name of Tlayúa Formation for the lithostratigraphic sequence exposed along this ravine, which he divided into three different carbonated members. The Middle Member is the most outstanding of Tlayúa Formation because its reddish and laminated limestones bear an abundant and taxonomically diverse fossil assemblage that shows extraordinary preservation. There is a strict stratigraphic control in Tlayúa, and the lithologic sequence exploited in this quarry is divided 
into 34 stratigraphic levels or "Zones", numbered as 1 to XXXIV from top to bottom (Figure 2). Besides its catalogue number, each fossil from this site is marked with its respective zone of occurrence.

Kashiyama et al. (2004) suggested that the fossiliferous strata of Tlayúa quarry represent an Aptian open marine sequence deposited into an intracratonic graben. In contrast, a middle-late Albian age for these strata was suggested by other authors and supported by the regional geology (Pantoja-Alor, 1992), biostratigraphy of ammonites and belemnites (Buitrón and Malpica-Cruz, 1987; Cantú-Chapa, 1987; Seibertz and Buitrón, 1987; Seibertz and Spaeth, 2002), and paleomagnetic signatures (Benammi et al., 2006). Applegate et al. (1982), Espinosa-Arruebarrena and Applegate (1996), and Applegate et al. (2006) suggested that these strata were deposited in a post-reef lagoon that they named the Tlayúa Lagoon. According to the last authors, this shallow transitional tropical depocenter was repeatedly connected to the sea, during high tides or strong storms, and it received sporadic freshwater flow from the land. In this way, during these connections, the living organisms and carcasses from sea and land were carried into the lagoon. The extraordinary fossil preservation in Tlayúa was possible by the episodic prolonged lack of water flow toward this lagoon, with high insolation, strong evaporation rates, and oxygen depletion that caused the massive mortality of trapped organisms and the slowdown of the organic decay (Applegate, 1996; Martill, 1989; Reynoso, 1998; Alvarado-Ortega et al., 2007).

Until now, the fossil assemblage of Tlayúa comprises invertebrate and vertebrate ichnites, algae, sponges, corals, foraminifers, ostracods, crabs, a few insects, ammonites, bivalves, gastropods, echinoderms, possible annelids, scarce terrestrial plant remains, and abundant vertebrates represented by crocodiles, pterosaurs, turtles, lizards, and tuataras, as well as a rich diversity of bony fishes and one batoid (Applegate et al., 1982, 2006, 2009; Applegate 1988; Feldmann et al., 1998; Alvarado-Ortega, 2004, 2005; GonzálezRodríguez et al., 2004, 2013; Martin-Medrano et al., 2009; Machado et al., 2013; González-Cruz, 2015; Brito et al., 2019; among others).

\section{MATERIAL AND METHODS}

Preparation methods. The specimens described in this work were prepared under the acid cleaning technique described by Toombs and Rixon (1959). Such a chemical treatment included the immersion of the fossils into a $5-10 \%$ acetic acid aqueous solution saturated with di-basic phosphate during periods of no more than three hours, which were alternated with immersion in running water for 12 hours. In each case, the acid solution and water immersion were applied until removal of the limestone from the fossil surfaces. Pin vices and needles were used under a binocular microscope to mechanically remove the remaining limestone patches. The specimens were observed and photographed under different illumination conditions, under white, natural, and long-wave UV (254 nm) light. The specimens were coated with magnesium dust to get high contrast gray-tone photographs.

Anatomical nomenclature. The anatomical nomenclatures and abbreviations used in this work follow those used in other studies (Grande, 1982, 1985; Forey et al., 2003; Di Dario, 2004; among others). These abbreviations are: aa, anguloarticular; ac, anterior ceratohyal; afr, anal fin ray; afs, anal fin stay; ao, antorbital; appt, anal proximal pterygiophore; bh, basihyal; br, branchiostegal ray; cl, cleithrum; cor, coracoid; cs, caudal scute; ddml depression for the dento-maxillar ligament; den, dentary; dfr, dorsal fin ray; dfs, dorsal fin stay; dh, dorsal hypohyal; dppt, dorsal proximal pterygiophore; dppt, proximal pterygiophores of dorsal fin; dsph, dermosphenotic; ect, ectopterygoid; ent, endopterygoid; ep, epural; epl, epipleural; epn, epineural; epn, epineural; epo, epioccipital; ext, extrascapular; fr, frontal; hapu, hemal arch of preural centrum; hm, hyomandibular; hy, hypural; io, infraorbital; iop, interopercle; le, lateral ethmoid; mes, mesethmoid; mp, metapterygoid; $\mathrm{mx}$, maxilla; na, nasal; naac, neural arches + spines of abdominal centrum; napu, neural arch of preural centrum; nau, neural arch of ural centrum; op, opercle; os, orbitosphenoid; pa, parietal; pal, palatine; pc, posterior ceratohyal; pcl, postcleithrum; pd, predorsal bone; pds, predorsal scutes; pfr, pectoral fin ray; php, parhypural; pop, preopercle; prl, branched and segmented caudal fin ray of lower lobe; prll, unbranched caudal principal fin ray of lower lobe; pru, branched and segmented caudal fin ray of upper lobe; prul, uncbranched caudal principal fin ray of upper lobe; prvas, prepelvic abdominal scute; psp, parasphenoid; pto, pterotic; pts, pterosphenoid; ptt, posttemporal; ptvas, postpelvic abdominal scute; pu, preural centrum; pvfr, pelvic fin ray; q, quadrate; rar, retroarticular; r, rib; rad, radial; rar, retroarticular; sc, sclerotic; sca, scapula; scl, supracleithrum; smx, supramaxilla; soc, supraoccipital; sop, subopercle; suo, supraorbital; sy, symplectic; u, ural centrum; uh, urohyal; un, uro- 
neural; upds, unmodified predorsal scales; vh, ventral hypohyal.

Institutional abbreviations. The specimens referred to in the present work are housed in the following institutions: DNPM, Departamento Nacional de Produção Mineral, Brazil. IGM, Colección Nacional de Paleontología, Instituto de Geología, Universidad Nacional Autónoma de México. IHNFG, Museo Eliseo Palacios Aguilera, Secretaria de Medio Ambiente e Historia Natural de Chiapas, Mexico. INAH, Instituto Nacional de Antropología e Historia, Chiapas, Mexico. NHM, Natural History Museum, London (before BMNH, British Museum of Natural History).

Comparative materials. This work considered the following specimens for comparative purposes. Armigatus brevissimus (Blainville, 1818): IGM 11532 (Figure 1), IGM 11533, IGM 11534, and IGM 11535, almost complete specimens from Cenomanian deposits of Hakel, Lebanon. Diplomystus dentatus Cope, 1877: NHM P.52501, NHM P.24790, NHM P.63596, NHM P.5218, all from Eocene lacustrine deposits of the Green River Shales, Wyoming, United States of America. Ellimmichthys longicostatus (Cope), 1886: DNPM 551P; Rio de Pixuma, Candeiras, Bahia, Brazil. Paraclupea-like (Alvarado-Ortega et al., 2008): IHNFG2331 (part and counterpart of the same specimen) from the El Espinal Quarry, Cintalapa Member of Sierra Madre Formation, Chiapas, Mexico. Paraclupea seilacheri Alvarado-Ortega and MelgarejoDamián, 2017: IGM 4717 (holotype), IGM 4718 to IGM 4723, all from the Albian deposits of the Tlayúa quarry, Puebla, Mexico. Ranulfoichthys dorsonudum Alvarado-Ortega, 2014: IGM 9034 (holotype), IGM 9035 to IGM 9047, and IGM 9467 and IGM 9468, all from the Albian deposits of the Tlayúa quarry, Puebla, Mexico. Scutatupinosus itapagipensis Santos and Correa, 1985: DNPM 1207P, 1208-P, 1209-P; Recôncavo Basin, Ilhas Group, Salvador, Bahia, Brazil. Triplomystus applegatei Alvarado-Ortega and Ovalles-Damián 2008, which was renamed as Scutatoclupea applegatei by Bannikov (2015): INAH 1941 (holotype); El Espinal Quarry, Cintalapa Member of Sierra Madre Formation, Chiapas, Mexico.

\section{SYSTEMATIC PALEONTOLOGY}

Superorder CLUPEOMORPHA Greenwood et al., 1966

Order ELLIMMICHTHYIFORMES Grande, 1982

Family ARMIGATIDAE Murray and Wilson, 2013 Genus ARMIGATUS Grande, 1982
Armigatus carrenoae sp. nov.

(Figures 3-10; Table 1)

zoobank.org/3FE49A65-4103-407E-AA74-80E201FAE866

Holotype. Specimen IGM 11536, complete skeleton from the level Zone XX (Figure 3).

Paratypes. IGM 11537, complete skeleton from unknown level (Figure 4A). IGM 11538, complete skeleton from unknown level (Figure 4B). IGM 11539 , complete skeleton from known level Zone X. IGM 11540, complete skeleton from known level Zone XIII (Figure 7). IGM 11541, complete skeleton from unknown level (Figure 4C). IGM 11542, complete fish from known level Zone XV. IGM 11543, resin-transferred incomplete skeleton from known level Zone XVII.

Range. 103 to $100.5 \mathrm{Ma}$, middle to late Albian (Benammi et al., 2006).

Occurrence. Marine laminar limestones of the Middle Member of Tlayúa Formation, exposed in Tlayúa quarry (Figure 1), near Tepexi de Rodríguez town, Puebla, Mexico (Applegate, 1987; Cantú-Chapa, 1987; Pantoja-Alor,1992; among others).

Etymology. The species name honors our colleague, Ana Luisa Carreño, for her valuable contributions to geology and paleontology of the Baja California Peninsula. The combination of the genus and species names mean "Carreño's armored fish."

Diagnosis. This is a deep-bodied Armigatus species in which the larger specimen known displays a maximum standard length (SL) of about $64.2 \mathrm{~mm}$; this species differs from other species of Armigatus by the following combination of characters: the maximum body height is around 50.4 (47.1-53.8) $\%$ of SL; the head length represents about 37.9 (35.8-40.2) \% of SL; the dorsal fin is relatively small, consists of 11 (rarely 12) dorsal rays, originates at $56.7(54.8-57.8) \%$ of SL, and its length represents $16.1(14.8-17.3) \%$ of SL; the anal fin is longer than the dorsal fin, consists of 17 (rarely 15) rays, originates at $78.8(76.7-81.4) \%$ of $\mathrm{SL}$, and is extended over 17.5 (16.5-18.9) \% of SL; the pelvic fin base is opposed to the posterior half of the dorsal fin and is placed at $58.9(56.8-60.4) \%$ of SL; the frontal, parietal, and pterotic bones are ornamented with ridges wide and conspicuous; the basal region of the opercular surface is ornamented with shallow and straight ridges, projecting dorsally from the ventral edge; it vertebral column has about 34 (33-35) vertebrae, including 16 (1517) abdominals, 17 (15-17) caudals, and two urals; the dorsal and abdominal edge of the trunk show two series of smooth scutes, the predorsal series 


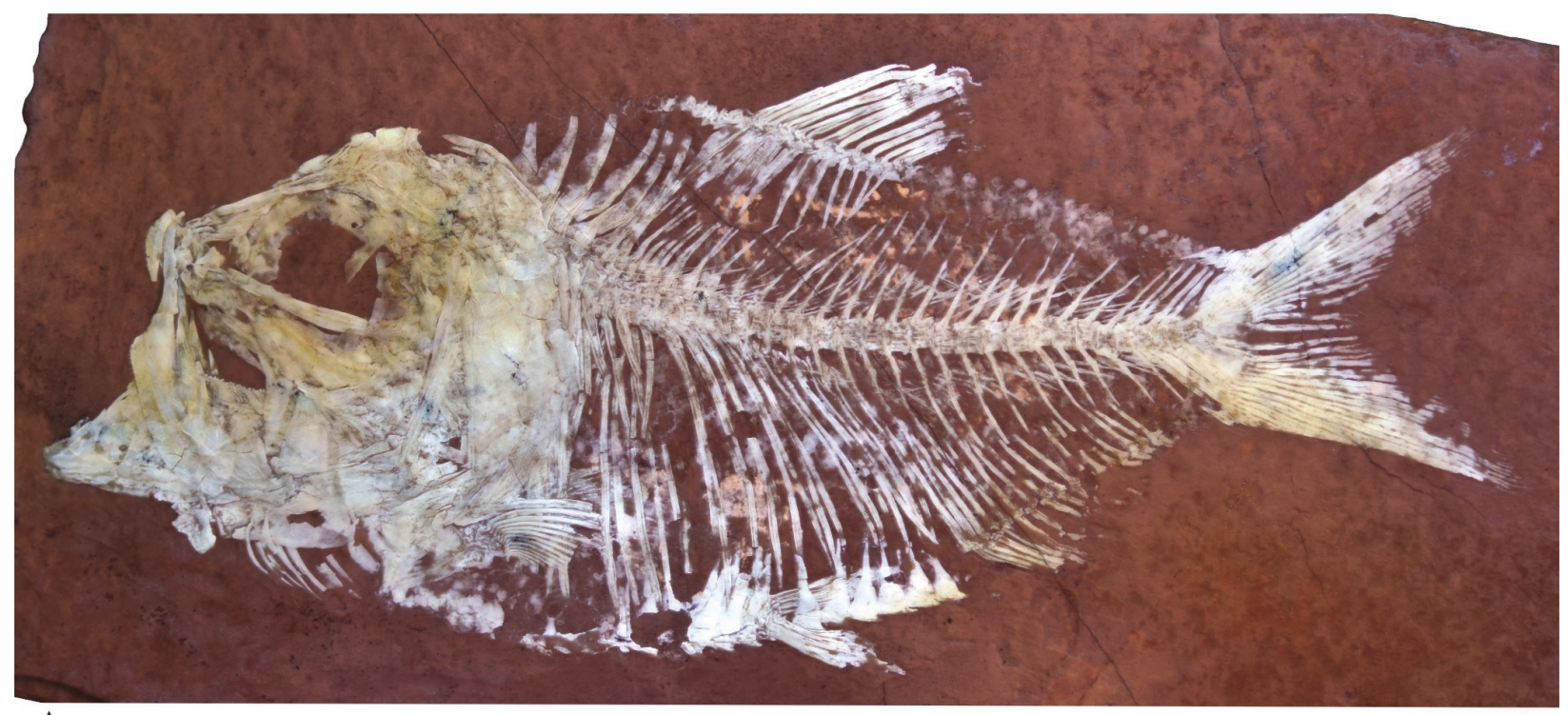

A

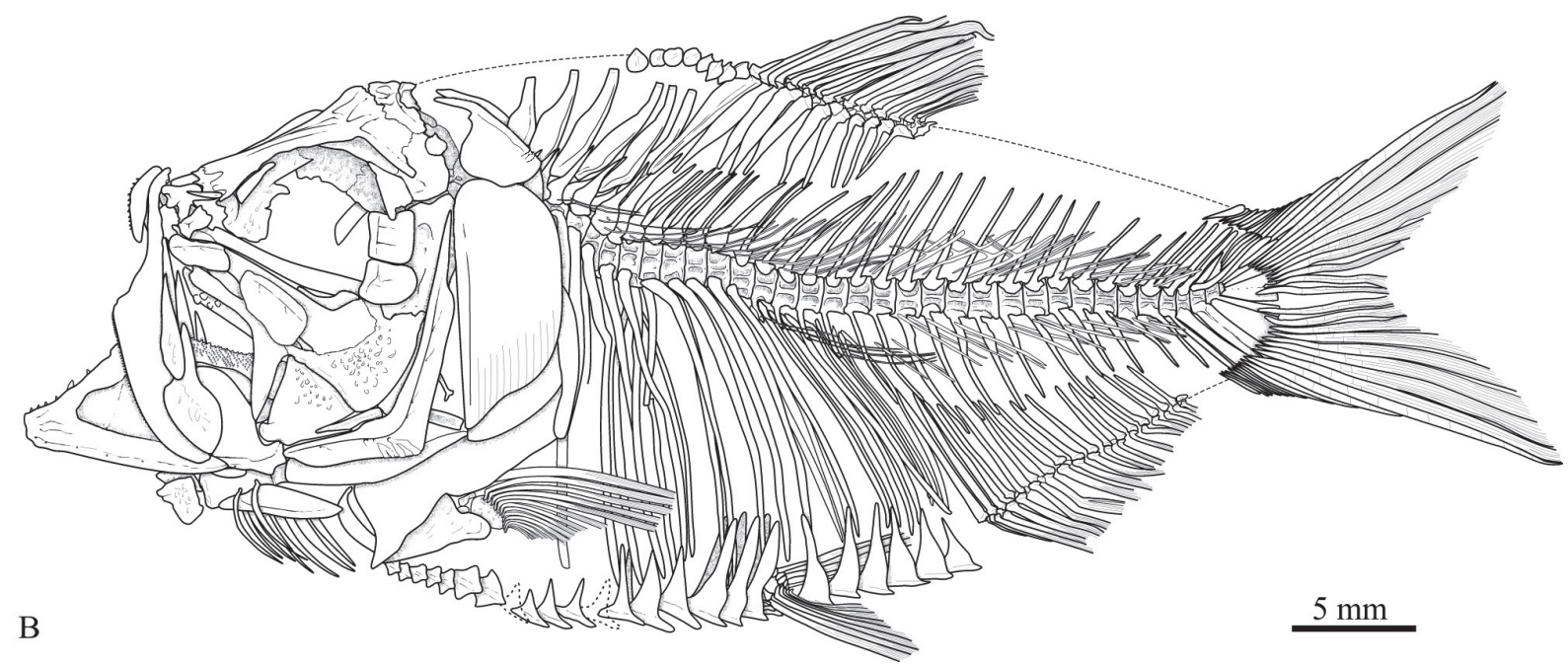

FIGURE 3. IGM 11536, holotype of Armigatus carrenoae sp. nov. from the Albian deposits of Tlayúa lagerstätte, near Tepexi de Rodríguez, Puebla, Mexico. A, photograph of the complete specimen under UV light. B, idealized drawing of the same specimen.

has eight scutes; the abdominal series consists of 23 (rarely 22) prepelvic scutes and six postpelvic scutes; the last predorsal scutes are subrectangular, larger than the anterior ones, and, bear a prominent posterior spine.

\section{Description}

General features and proportions. Table 1 summarizes the measurements and body proportions of the specimens described here as Armigatus carrenoae sp. nov. The overall body shape of this species resembles that of Armigatus brevissimus the type species of the genus. This high-bodied fish has a large triangular head, on average $37.9 \%$ of SL (ranging between 35.8 and $40.2 \%$ ), that is about 1.3 times longer than high. The short mouth opens slightly upward, the lower jaw is articulated with the skull below the level of the middle of the orbit. The maximum body height is in the predorsal region of the trunk and represents 50.4 (47.1$53.8) \%$ of SL. The unpaired fins are in the posterior half of the body. The predorsal and preanal lengths are 56.7 (54.8-57.8) and 78.8 (76.7$81.4) \%$ of SL, respectively. The anal fin is posterior to and slightly longer than the dorsal fin (1.08 times). The pelvic fin is placed in opposition to the posterior half of the dorsal fin and rises at the beginning of the posterior half of the body length, at $58.9(56.8-60.4) \%$ of SL. The caudal peduncle is narrow and precedes a wide caudal fin that consists of two symmetrical caudal lobes that are approximately equal-sized. 


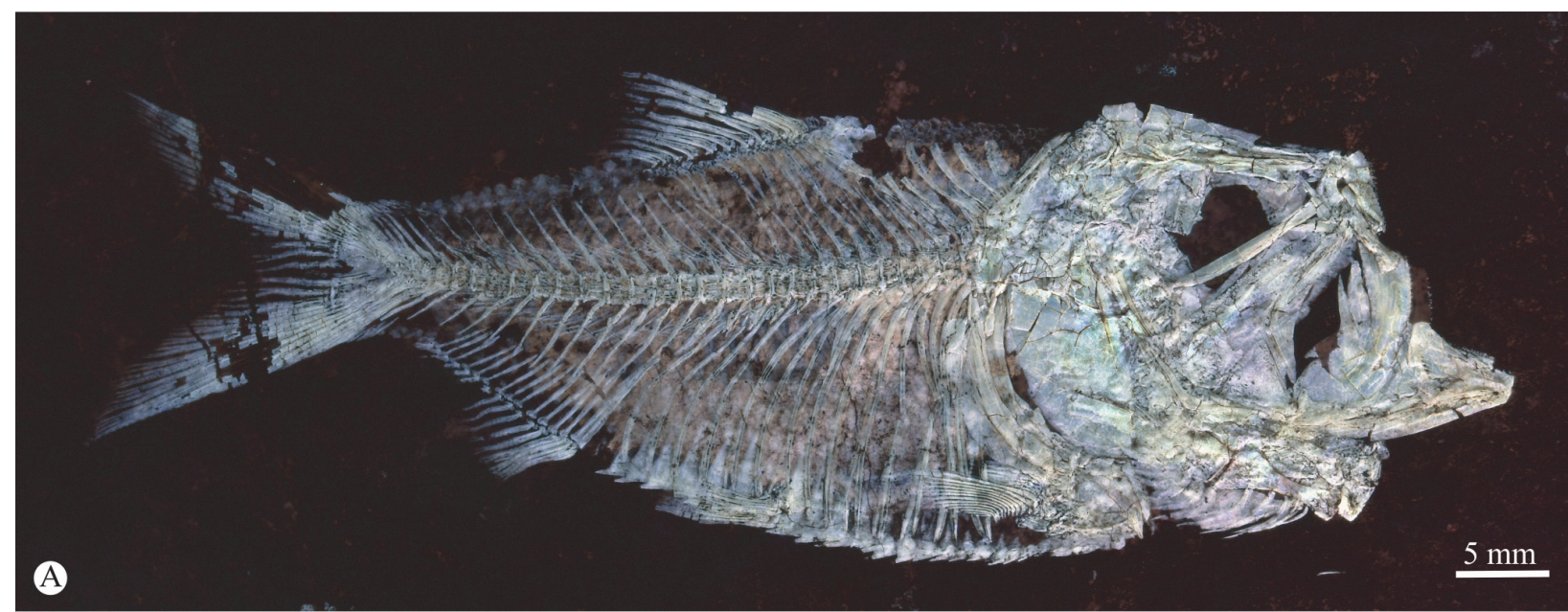

B
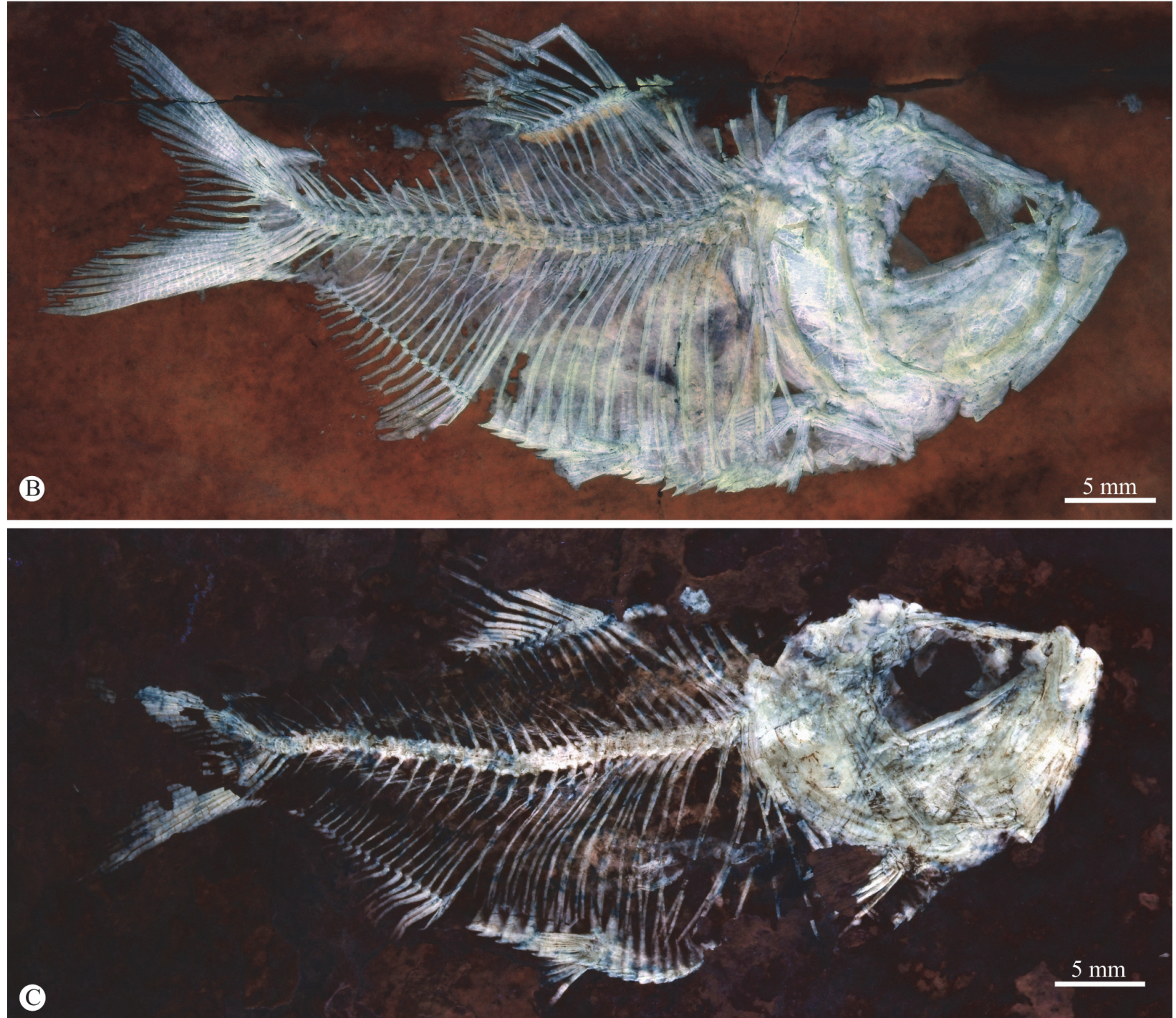

FIGURE 4. Paratypes of Armigatus carrenoae sp. nov. from Albian deposits of Tlayúa lagerstätte, near Tepexi de Rodríguez, Puebla, Mexico, photographed under UV light. A, IGM 11537. B, IGM 11538. C, IGM 11540. 
Skull. The head is laterally preserved in all specimens referred to Armigatus carrenoae sp. nov. (Figure 4). The skull is triangular, about 1.3 times longer than deep; its otic-occipital, orbital, and ethmoid sections are approximate of the same length. The frontal bones are roughly triangular, anteriorly sharp, and posteriorly wide; these form most of the skull roof. The posterior part of each frontal articulates the parietals posteriorly, the pterotic lateroposteriorly, and the dermosphenotic laterally. There are no interfrontal fontanelles. The parietals are large sub-square bones that meet each other along the midline, separating the supraoccipital from the frontals. The supraoccipital is a small bone that forms a delicate crest. The parietals entirely suture the frontals, epioccipital, and pterotic bones; therefore, there is no temporal foramen or the pre-epiotic fossa. The pterotic is a roughly rectangular bone on the lateral skull wall. There is no evidence of the recessus lateralis on lateral skull bones. The anterior part of the frontals, as well as the parietals and pterotics, are strongly ornamented with a reticular pattern of ankylosed sigmoid ridges that enclose the temporal and supraorbital canals. The parietals carry the supratemporal commissural sensory canal.

The orbitosphenoid has a ventral projection that protrudes into the orbit below the frontals. The pterosphenoid and basisphenoid bones form the posterior inner wall of the orbit. The orbital part of the parasphenoid is edentulous and bears an anteroventral elongated basipterygoid process. Behind its basipterygoid process, the postorbital part of the parasphenoid has the osteoglossid-like tooth patch with at least seven short and conical teeth with sharp tips (Figure 7). The anterior tip of the parasphenoid bone sutures a smooth small bone here identified as the vomer.

The mesethmoid is a complex and unpaired bone posteriorly overlapped and articulated with the frontals (Figure 5). IGM 11540 shows that in dorsal view the mesethmoid is a star-shaped bone, which has a rounded anterior process, two lateral processes projected anteroventrally, and a flat rear that is somewhat laterally expanded. Between the middle-anterior and each lateral-posterior process, there is a deep rounded depression that contains the articular facet for the maxilla and premaxilla. The tip of the lateral-posterior process has a slightly concave facet for the palatine head. The lateral ethmoid is a roughly rectangular bone that separates the nasal capsule from the orbit and is strongly attached to the anterodorsal edge of the parasphenoid and the inner ventral surface of the respective frontal. The nasal is a small tubular bone.

Upper jaw. This consists of four flat and thin bones: the premaxilla, maxilla, and two supramaxillae (Figure 5). The maxilla is a saber-shaped bone with two sections; its anterior toothless section is a rod-like and slightly curved structure that occupies approximately $40 \%$ of the anterior part of the bone and dorsally bears two short dorsal articular processes, the terminal mesethmoid processes and the palatine processes located in the middle. The toothed section of the maxilla is a curved spatulalike structure that has a middle thick bar extending for the full length of the bone, forming a noticeable bulge exposed on the labial surface. A row of small conical teeth occupies the entire ventral edge of the toothed section. These teeth are regular-sized, closely spaced, and have tips that curve slightly backward.

The premaxilla is sickle-shaped bone with a thick dorsal edge, in which the alveolar region is expanded, the ventral edge is slightly curved, and the anterior ascending process is small (Figure 5). The premaxilla lies below the anterior half of the toothless section of the maxilla. A large part of the premaxillary labial surface is smooth; however, this surface shows numerous pores and a series of sinuous dorsoventral grooves near the alveolar border. A single row of small conical teeth occupies the premaxillary alveolar border. These teeth have acute tips curved backward that become slightly smaller in posterior positions and are uniformly spaced, leaving empty inter-dental spaces.

Two laminar, elongated, and drop-shaped supramaxillae overlap the posterior section of the maxilla (Figure 5). The anterior supramaxilla is smaller than the posterior one. The posterior supramaxilla is noticeably expanded, long, and almost reaches the anterior tip of the anterior supramaxilla. Sinuous wrinkles ornament the expanded sections of the supramaxillae.

Lower jaw. This consists of the dentary, anguloarticular, and retroarticular bones. The lower jaw is a triangular structure with a short ventral postarticular process, shallow symphyseal edge, and a smoothly convex ventral edge (Figures 5, 6). Here the alveolar edge is short, sinuous, and strongly tilted upward while the coronoid process is rounded but hardly distinguishable.

In labial view, the dentary is a triangular bone deeply forked posteriorly, in which the dorsal limb forms the coronoid process and extends backward along the dorsal edge of the retroarticular bone (Figures 5,6). The ventral dentary limb is extended 


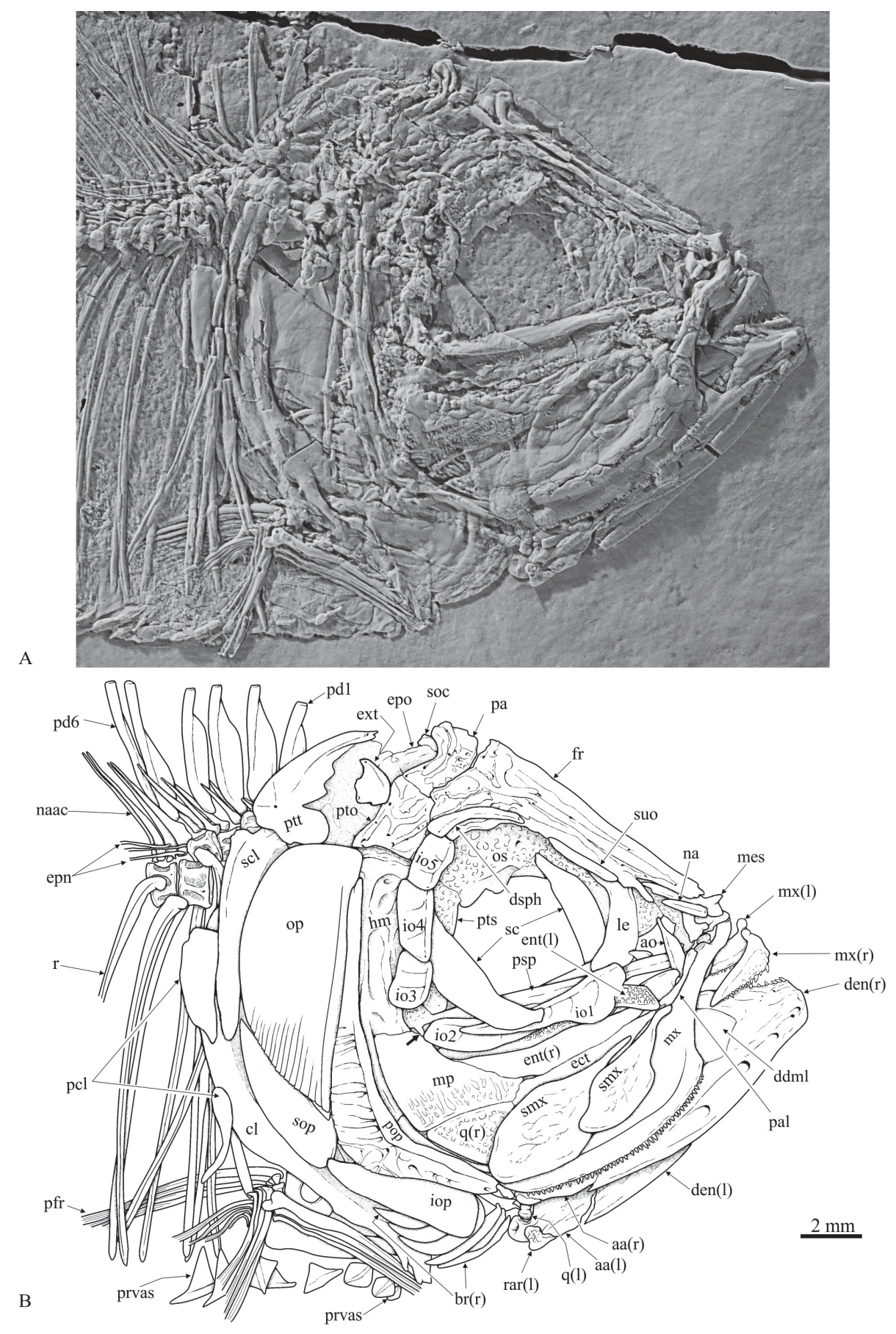

FIGURE 5. Head of Armigatus carrenoae sp. nov. from the Albian deposits of Tlayúa lagerstätte, near Tepexi de Rodríguez, Puebla, Mexico. A, Closeup of IGM 11538, coated with magnesium smoke and photographed under white light. B, idealized and simplified drawing of A. Abbreviations: aa, anguloarticular; ao, antorbital; br, branchiostegal ray; cl, cleithrum; ddml depression for the dento-maxillar ligament; den, dentary; dsph, dermosphenotic; ect, ectopterygoid; ent, endopterygoid; epo, epioccipital; epn, epineurals; ext, extrascapular; fr, frontal; hm, hyomandibular; io, infraorbital; iop, interopercle; le, lateral ethmoid; mes, mesethmoid; mp, metapterygoid; mx, maxilla; na, nasal; naac, neural arches + spines of abdominal centrum; op, opercle; os, orbitosphenoid; os, orbitosphenoid; pa, parietal; pal, palatine; pcl, postcleithrum; pd, predorsal; pfr, pectoral fin ray; pop, preopercle; prvas, prepelvic abdominal scutes; psp, parasphenoid; pto, pterotic; pts, pterosphenoid; ptt, posttemporal; q, quadrate; r, rib; rar, retroarticular; sc, sclerotic; scl, supracleithrum; smx, supramaxilla; soc, supraoccipital; sop, subopercle; suo, supraorbital; dark arrow shows the basipterygoid process of the parasphenoid bone; $(\mathrm{l})$ and $(r)$ indicates the left and right side. 

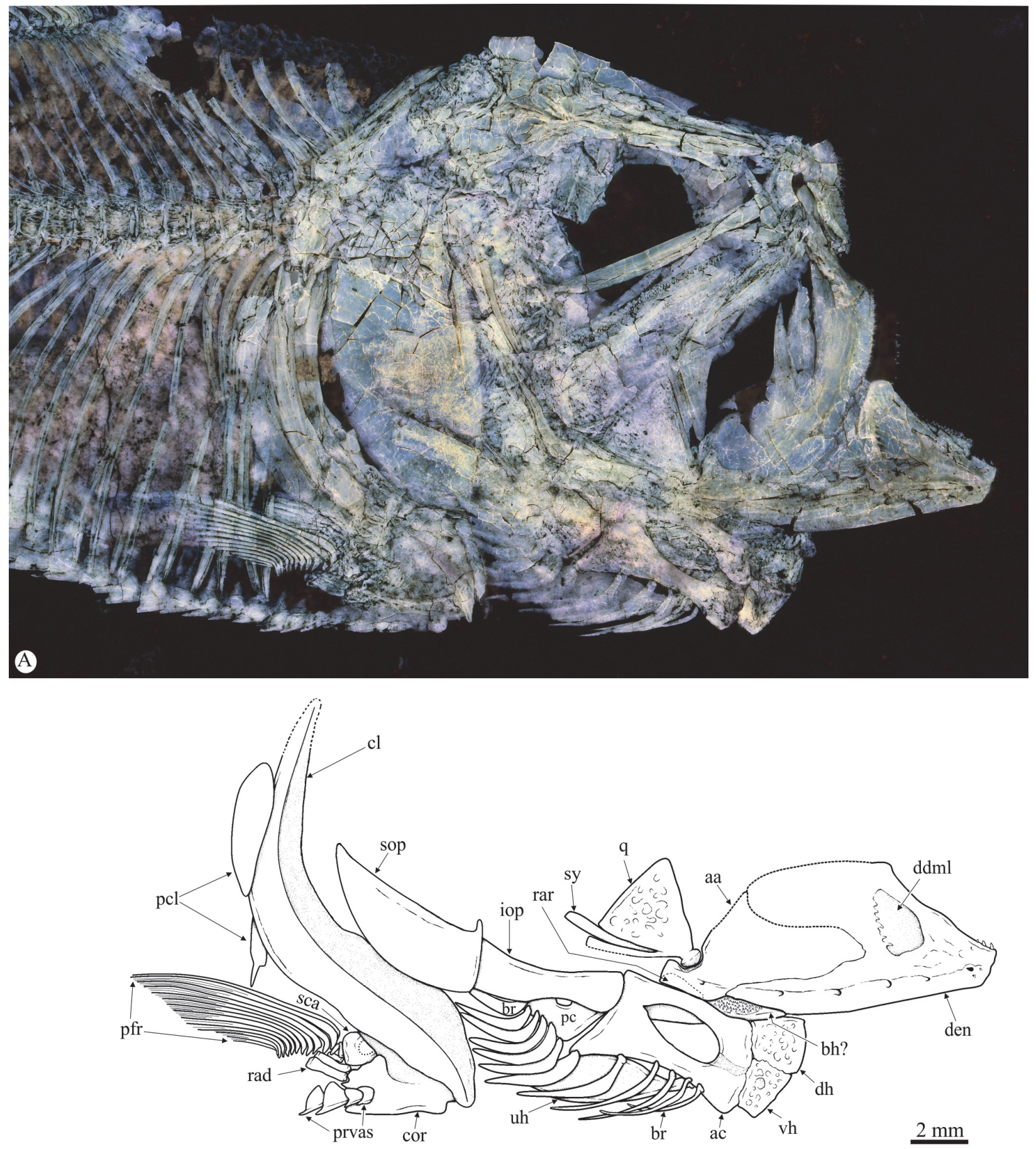

$\mathrm{B}$

FIGURE 6. Part of the pectoral girdle, lower jaw, branchial arch, and branchiostegal rays of Armigatus carrenoae sp. nov. from the Albian deposits of the Tlayúa lagerstätte, near Tepexi de Rodríguez, Puebla, Mexico. A, closeup of the head of the paratype IGM 11537 under UV light. B, idealized and simplified drawing based on A. Abbreviations: aa, anguloarticular; ac, anterior ceratohyal; bh, basihyal; br, branchiostegal ray; cl, cleithrum; cor, coracoid; ddml depression for the dento-maxillar ligament; den, dentary; dh, dorsal hypohyal; iop, interopercle; pc, posterior ceratohyal; pcl, postcleithrum; pfr, pectoral fin ray; prvas, prepelvic abdominal scutes; q, quadrate; rar, retroarticular; rad, radial; sca, scapula; sop, subopercle; sy, symplectic; uh, urohyal; vh, ventral hypohyal. 
backward almost up to the base of the postarticular process. Below the posterior part of the alveolar border, the labial surface of the dentary shows a conspicuous, shallow, and oval depression for the attachment of the infralabial ligament or dentomaxillar ligament (i.e., Osse, 1969; Datovo and Vari, 2013). In this bone, a tooth row is present along the alveolar border. Dentary teeth resemble those of the premaxilla.

The anguloarticular bone occupies about the last third of the lower jaw, forms the bulk of the postarticular process, and forms the entire articular facet for the quadrate (Figures 5, 6). A small retroarticular occupies the ventral end of the postarticular process and does not participate in the articular facet for the quadrate. The articulation between the quadrate and lower jaw is exposed laterally. The mandibular sensory canal runs near the ventral border of the dentary and retroarticular bones and opens through small pores near the symphysis, four or five large pores in the dentary, and at least two pores in the anguloarticular.

Circumorbital bones. These flimsy and flat bones almost enclose the orbit (Figure 5). Unfortunately, the circumorbitals are poorly preserved in referred specimens because these were strongly deformed or broken by the compression against the skull. These bones include a comparatively small oval antorbital bone that is higher than long and covers the lateral surface of the nasal capsule. An elongated supraorbital bone borders the anterodorsal orbital section. The dermosphenotic is an elongated subtriangular curved bone, expanded posteriorly, which borders the posterodorsal orbital region. At least five infraorbitals are present; the first two are elongated and border the ventral orbital section while infraorbitals 3-5 are somewhat rectangular and form the posterior border of this cavity. The infraorbital sensory canal runs alongside the orbital edges of the infraorbital bones and opens through some inconspicuous and scattered pores. The orbit is occupied by a couple of large flat wedge-shaped sclerotic bones.

Suspensorium. Bones of the suspensorium are only partially exposed (Figures 5,6 ). The hyomandibular is a hatchet-like bone with a single stout head and a narrow long ventral shaft bearing a posterior opercular process that is poorly developed. The quadrate is a flat triangular bone placed beneath the anterior half of the orbit and has a stout articular head inclined forward and downward. The posterior process of the quadrate is thin and slightly dorsally expanded. The symplectic is a stake-shaped bone that is tilted backward and higher than the quadrate.

The metapterygoid is roughly triangular, and its lingual surface seems to be toothless. The ectopterygoid is gracile and boomerang-shaped, in which the vertical and horizontal limbs form an obtuse angle of about $100^{\circ}$. The ectopterygoid meets the ventral border of endopterygoid and the anterior edge of the quadrate. In the holotype, the ectopterygoid bears a patch of small teeth (Figure 5). The endopterygoid is an oblong and flat bone that bears numerous short conical teeth of regular size. The palatine is a robust bone medially expanded and posteriorly pointed. The palatine head is small, stout, and joins with the lateral-posterior process of the mesethmoid and the posterior maxillary palatine facet (Figures 5,6 ).

Opercular bones. The opercle is a flat kidneyshaped bone, higher than long, in which the anterior edge is straight and thickened. The hyomandibular facet is located near the anterior edge and at the beginning of the upper quarter of the opercular height. This bone is superficially smooth except for its basal quarter that is covered with shallow, straight, and parallel grooves of uneven height and uniformly spaced, which extend from the ventral edge. The subopercle is a flat, semicircular, smooth, and dorsally straight bone with a sharp anterior ascending process that is extended along the ventral edge of the opercle.

The preopercle is a flat and inverted L-shaped bone with smooth edges, in which the vertical limb height is twice the horizontal limb length (Figure 5).

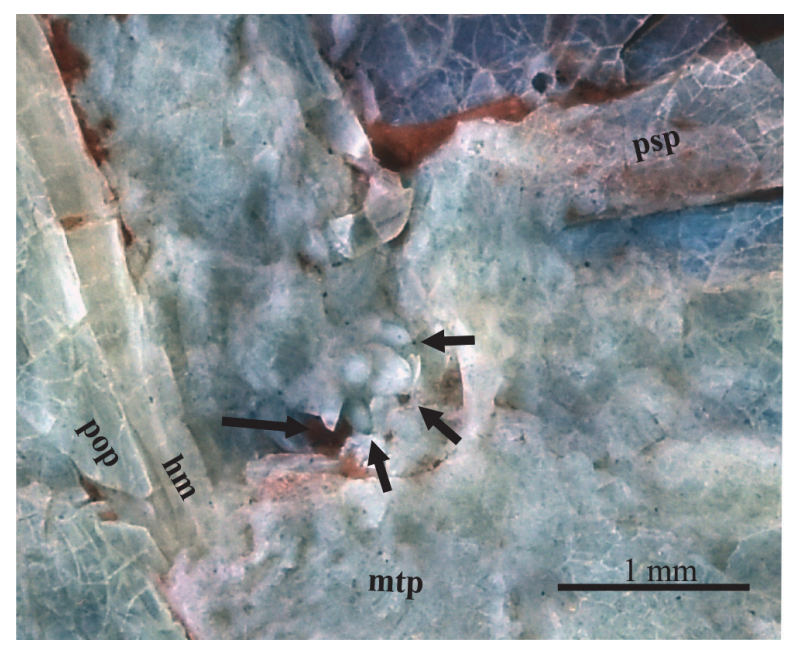

FIGURE 7. Closeup of the postorbital region of IGM 11539 showing the osteoglossid-like tooth patch on the parasphenoid bone (black arrows). Abbreviations: hm, hyomandibular; mtp, metapterygoid; pop, preopercle; psp, parasphenoid. 
The dorsal tip of this bone reaches the opercular dorsal edge. The preopercular sensory canal runs close to the anterior edge of its vertical limb and dorsal edge of its horizontal limbs; around the commissure of these limbs, this sensory canal shows four to seven wide and sinuous branches. The interopercle is a flat, smooth, and spatula-shaped bone.

Branchiostegal rays and branchial arch. In the available specimens, the branchial arch elements known are partially covered (Figures 5, 6). The hypohyals are thick, flat, and smooth rectangular bones; the dorsal hypohyal is slightly higher than long while the ventral hypohyal is about twice higher than long.

The anterior ceratohyal is rectangular, about twice longer than high, centrally pierced by a large beryciform foramen, and has a horizontal groove for the afferent hyoidean artery. The posterior ceratohyal is flat, semicircular with the anterior edge straight and centrally pierced by an elongated small foramen. The urohyal is a complex elongated bone with an anterior small and massive head, a basal flat wing that is laterally expanded, and a central flange upward expanded. There are 10 or 11 flat blade-like branchiostegal rays.

Bones of the branchial series are largely covered by more superficial bones. Despite this situation, in IGM 11537, the anterior part of the basihyal bone is exposed showing a noticeable dorsal patch of numerous, small, and conical teeth (Figure 6).

Axial skeleton. The vertebral column consists of 33 to 35 total centra, including $15-17$ abdominals, 15-17 preurals, and two urals (Figure 8, Table 1). All centra are constricted in the middle and superficially sculpted with longitudinal cavities. The abdominal and anterior caudal centra are slightly higher than long; beyond, the middle caudal centra become longer than high, being in the most extreme cases about 1.25 times longer than high. The posterior preural centra and both urals tend to be smaller. The intervertebral surfaces of centra

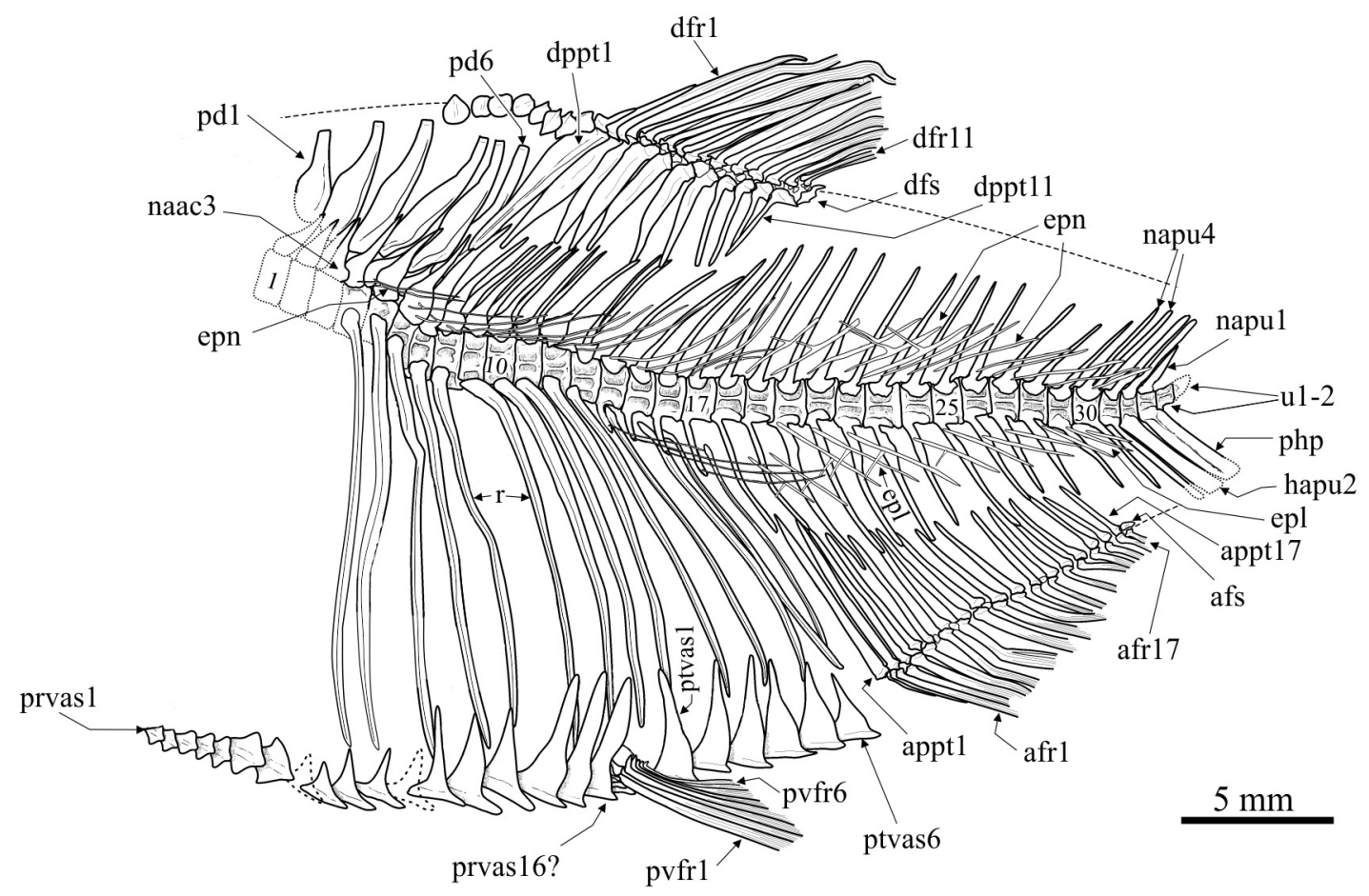

FIGURE 8. Idealized and simplified drawing of the trunk and pelvic, anal, and dorsal fins of IGM 11536, holotype Armigatus carrenoae sp, nov. from the Albian deposits of Tlayúa lagerstätte, near Tepexi de Rodríguez, Puebla, Mexico (based on Figure 3). Abbreviations: afr, anal fin ray; afs, anal fin stay; appt, anal proximal pterygiophore; dfr, dorsal fin ray; dfs, dorsal fin stay; dppt, proximal pterygiophores of dorsal fin; epl, epipleural; epn, epineural; hapu, hemal arch and spine of preural centrum; naac, neural arch of abdominal centrum; napu, neural arch and spine of preural centrum; napu4, preural centrum 4 with double neural spine; pd, predorsal bone; php, parhypural; prvas, prepelvic abdominal scute; ptvas, postpelvic abdominal scute; pvfr, pelvic fin ray; r, rib; u, ural centrum; numbers under centra indicate their position along the vertebral column. 
are concave and pierced by a small notochordal foramen.

The anterior abdominal centra have hypertrophied neural arches consisting of unfused hemiarches that are rounded and slightly expanded that fit into the dorsolateral cavity of the respective centrum; therefore, there are bifid neural spines on each of these abdominal centra. Posteriorly, the neural arches are tightly attached or perhaps fused with the centra, are progressively less high, and have a single neural spine. All caudal centra are fused with the respective neural and hemal arches that carry a single neural and hemal spine. In IGM 11536, the arch of preural centrum 4 has two spines, one in front of another (Figure 8).

The abdominal cavity is almost entirely enclosed by 14 or 15 pairs of long curved ribs (Figure 8). Two-thirds of these ribs have expanded heads to articulate with the ventrolateral cavities of the respective abdominal centra. The other ribs have expanded heads to articulate with the parapophyses developed in the anterior part of the most posterior eight abdominal centra. The sizes of the parapophyses increase in anterior to posterior order. There are six stick-like and slightly curved predorsals located between the occiput and the dorsal pterygiophores. In these bones, there is an anterior laminar extension that tends to be reduced in larger specimens.

Long and flat epineural bones are associated with all the neural arches and spines except for those of the preurals 1 to 3 . In the abdominal region, the epineurals have anterior tips forked, are very thin, curved upward, and as long as five to six centra. In the anterior caudal centra, the epineurals are comparatively stouter, shorter, and exhibit a peculiar Y-shape, in which the three radiating limbs are equally long and those projected forward form an acute anterior angle. In the posterior caudal centra, the epineurals are parallel with the vertebral column and comparatively broader and shorter. Parapophyses of the abdominal centra and the neural arches and spines of the caudal centra, except for the last three preurals, are associated with long flat epipleurals. The shapes and sizes of the epipleurals are mirrored symmetrically to those of the epineurals above. There are no epicentral bones.

Pectoral girdle and fins. The posttemporal is a flat, oval, and long bone that has an elongated and thin rectangular dorsal process and an expanded ventral process (Figure 5). The posterior ventral edge of this bone is crenulated. In comparison with the posttemporal, the ovoidal extrascapular bone is small.

The supracleithrum is flat, subrectangular, slightly curved, and rests on the dorsal limb of the cleithrum (Figures 5, 6). In lateral view, the cleithrum is an S-shaped structure, in which the extremely short horizontal middle region separates the high posterior vertical limb from the relatively low anterior vertical limb. Posterior to the anterior vertical limb of the cleithrum, parts of the coracoid and the scapula are exposed. Two long, ovoidal, and flat postcleithra are present; the ventral one has a narrow ventral end.

At least five radials are inserted between the scapular and the pectoral fin rays; these are short and rod-like bones with both extremes rounded and expanded. The pectoral fin consists of a series of 15 distally branched and segmented rays (Figure 6), in which the first ray is as long as seven abdominal centra and almost covers the distance between the pectoral and the pelvic fins. Other pectoral rays become shorter.

Pelvic girdle and fins. This small fin is opposed to the anterior half of the dorsal fin and consists of five to seven distally branched and segmented rays that are extended backward beneath the sixth and seventh abdominal centra. The pelvic girdle consists of two unfused elongated triangular pelvic bones that lie beneath three abdominal centra, have sharp anterior tips, and are about twice longer than wide (Figure 8).

Dorsal fin. This short triangular fin originates just behind the middle of the body and extends above eight abdominal centra. This fin consists of two procurrent rays plus 11 to 13 rays. The fourth dorsal ray is the longest (Figure 8).

A series of 11 to 12 rod-like proximal pterygiophores support the dorsal fin. These have expanded articular heads. Among these bones, the anterior six have anterior and posterior laminar wings. Some elongated dorsal middle pterygiophores and rounded dorsal distal pterygiophores are exposed in the dorsal fin of the referred specimens. A short hook-like dorsal fin stay is present at the end of the dorsal fin support.

Anal fin. This long triangular fin lies beyond the dorsal fin and its base equals the length of 9-10 caudal centra (Figure 8). This fin consists of two small procurrent rays plus 15-17 elongated rays. The fourth anal fin ray is the longest. A series of 16 to 18 proximal pterygiophores supports this fin. These rod-like pterygiophores occupy the interhemal spaces and show articular heads anterior and posteriorly expanded. Inconspicuous anterior and 

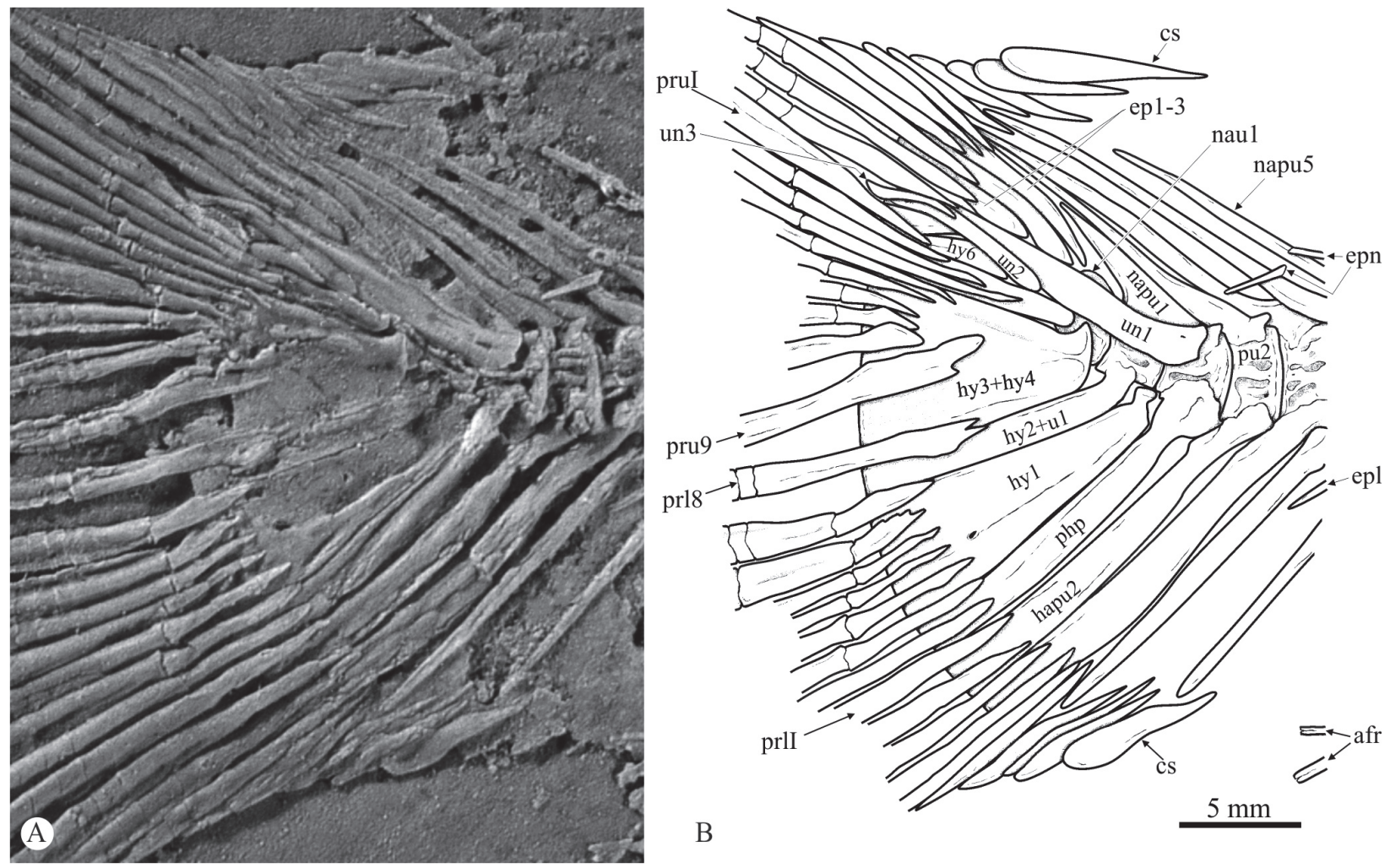

FIGURE 9. The caudal skeleton of Armigatus carrenoae sp. nov. from the Tlayúa Lagerstätte, near Tepexi de Rodríguez, Puebla, Mexico. A, closeup of the caudal skeleton of IGM 11538 coated with magnesium smoke. B, idealized and simplified drawing of A. Abbreviations: afr, anal fin ray; cs, caudal scute; ep, epural; epl, epipleural; epn, epineural; hapu, hemal arch of preural centrum; hy, hypural; napu, neural arch of preural centrum; nau, neural arch of ural centrum; php, parhypural; prl, branched and segmented caudal fin ray of the lower lobe; prll, unbranched caudal principal fin ray of the lower lobe; pru, branched and segmented caudal fin ray of the upper lobe; prul, unbranched caudal principal fin ray of the upper lobe; pu, preural centrum; u, ural centrum; un, uroneural.

posterior laminar wings are present in the anterior two or three proximal pterygiophores. Some rounded middle or distal pterygiophores are preserved. A short and stout anal fin stay is present at the end of the fin support.

Caudal fin. The hemal and neural spines of preurals 1-3 are thick and tilted backward supporting the caudal fin (Figure 9). This fin is deeply forked and has two elongated triangular lobes preceded by a single large drop-shaped caudal scute. The ventral caudal lobe is slightly longer than the dorsal one. The caudal formula is $x+1+9-8+1+i x$. The proximal ends of the principal rays are acute except for the inner rays of both lobes that rest on the hypurals 2-4, whose proximal ends are slightly branched and expanded.

The parhypural is thick, wide, and fused with the preural 1 . The neural arch of preural 1 is triangular and shorter than the anterior neural spines. The ural centrum 1 has a small neural arch. There are three stout, rod-like, and equally long epurals.
Ural centrum 1 is slightly larger than ural centrum 2 ; the first is in contact with the anterior tip of hypural 1 and fused with hypural 2 whereas the ural centrum 2 bears the hypurals 3 to 6 . There are six hypurals, the first is triangular and the wider in the series; others are rectangular and progressively smaller except for the hypurals 3 and 4 that are fused forming a triangular hypural plate. There is no caudal diastema or space between the hypural 2 and hypural 3 . There are no urodermals. Three uroneurals cover the dorsal surface of preural 1 and both ural centra. Uroneural 1 is the longest in the series, somewhat curved, and anteriorly expanded. The distal tip of uroneural 2 reaches the distal tip of uroneural 1. Uroneural 3 is the smallest in the series and rests near the distal ends of uroneurals 1 and 2 .

Scales and scutes. The entire trunk is covered with oval cycloid scales, higher than long, ornamented with numerous concentric circulli. Unfortunately, it is not possible to know the number of 

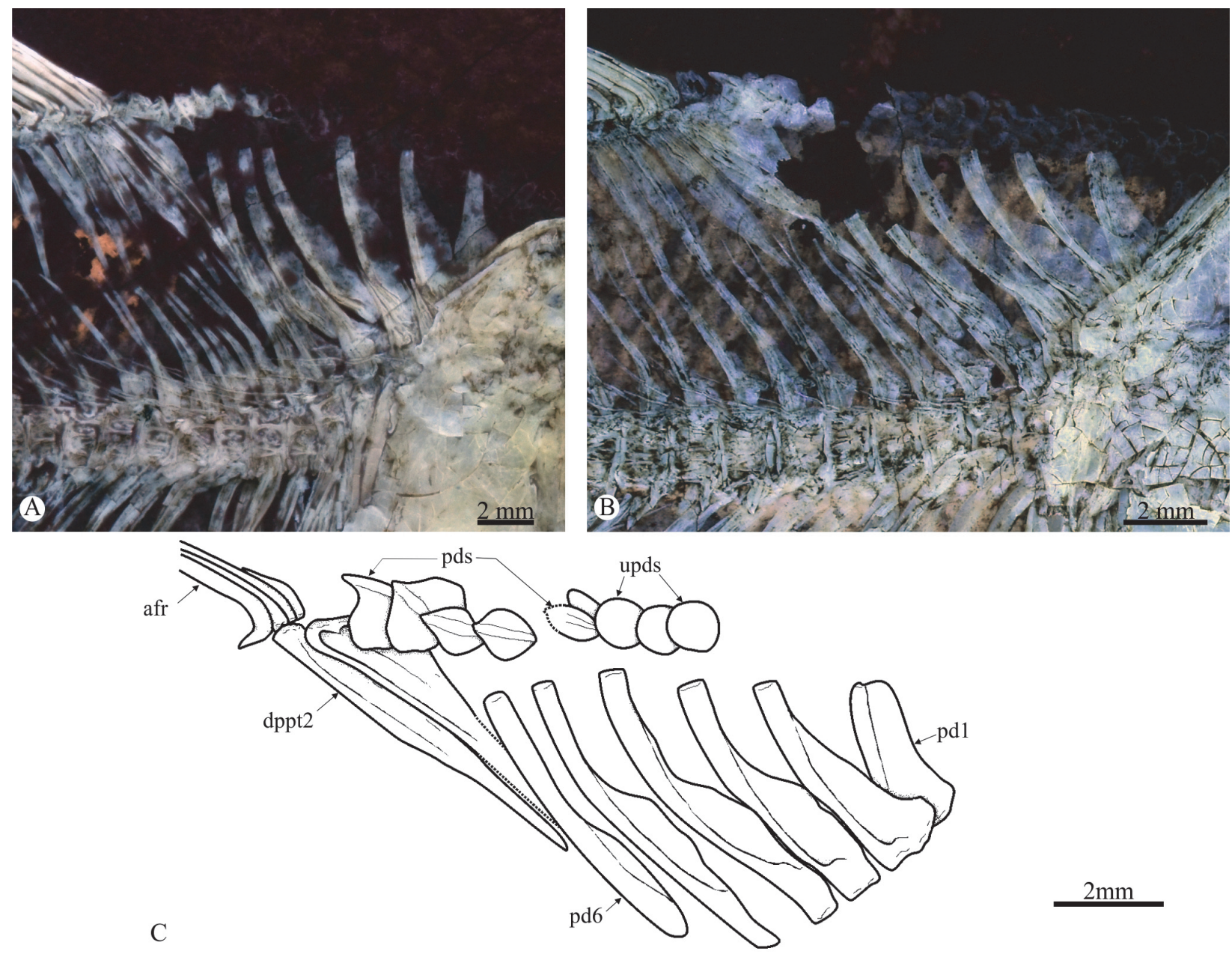

$2 \mathrm{~mm}$

FIGURE 10. Predorsal scutes series of $A$. carrenoae sp. nov. from Tlayúa. A, closeup of the predorsal region of IGM 11536 (inverted for comparative purposes). B, closeup of predorsal region of IGM 11537. C, idealized drawing of B. Abbreviations: afr, anal fin ray; pd, predorsal bone; pds, predorsal scutes; dppt, dorsal proximal pterygiophore; upds, unmodified predorsal scales.

scale rows and the existence of the lateral line. The predorsal and abdominal borders of the trunk are armored with scutes (Figure 10).

The predorsal scute series consists of eight scutes that lay over the posteriormost three predorsal bones and covers the posterior half of the predorsal edge of the body, near the dorsal fin base. Each predorsal scute rests on the anterior part of the successive one. The size and shape of these scutes change along the series; the anterior ones are small and oval while the posteriors become larger and subtriangular because they are laterally expanded. All predorsal scutes have a thick longitudinal middle keel; however, in the posteriormost ones, the keel is hypertrophied and forms a stout posterior spine. These scutes are superficially ornamented with a few inconspicuous sinuous ridges.
The abdominal scute series borders the ventral edge of the trunk, between the isthmus and the anus (Figures 3,8 ). The series consists of 22 to 23 scutes, including 16 to 17 prepelvics and six postpelvics. Overall, these smooth scutes have a triangular wing extended over each abdominal side, an anterior rounded tip, and an acute posterior projection; the posterior tip of one scute covers the anterior tip of the subsequent posterior one. These scutes also have a thick anteroposterior middle keel, which becomes a spine in the postpelvic scutes. The lateral wings of these scutes change along the series; in the middle, the ventral quarter of the abdominal cavity is covered by the largest lateral wings, anterior and posteriorly the wings of remaining scutes are progressively smaller.

Soft tissues and gut contents. As it occurs in other fossil fishes of Tlayúa reported by Alvarado- 
TABLE 1. Measurements and proportions of specimens of Armigatus carrenoae sp. nov. from the Tlayúa quarry referred here. All the measurements are given in millimeters, and all percentages are calculated on the base of the standard length (SL).

\begin{tabular}{|c|c|c|c|c|c|c|c|c|c|}
\hline & $\begin{array}{l}\text { IGM } \\
11536\end{array}$ & $\begin{array}{c}\text { IGM } \\
11537\end{array}$ & $\begin{array}{l}\text { IGM } \\
11538\end{array}$ & $\begin{array}{l}\text { Measurements } \\
\text { (in mm) and } \\
\text { proportions } \\
\text { IGM } 11539\end{array}$ & $\begin{array}{l}\text { IGM } \\
11540\end{array}$ & $\begin{array}{l}\text { IGM } \\
11541\end{array}$ & $\begin{array}{l}\text { IGM } \\
1542\end{array}$ & $\begin{array}{l}\text { IGM } \\
11543\end{array}$ & Avg. (Range) \\
\hline Total length & 57.2 & 68.3 & 57 & $81.9 ?$ & 35.3 & 57.5 & $56.6 ?$ & $68.3 ?$ & $55.6(35.3-68.3)$ \\
\hline Standard length & 42.7 & 50.1 & 42.4 & $64.2 ?$ & 49.7 & 46.0 & $46.9 ?$ & 51.8 & $47.1(18.4-51.8)$ \\
\hline $\begin{array}{l}\text { Body height } \\
\% S L\end{array}$ & $\begin{array}{l}23.0 \\
53.8\end{array}$ & $\begin{array}{l}23.7 \\
47.3\end{array}$ & $\begin{array}{l}22.7 \\
53.5\end{array}$ & $\begin{array}{c}27.3 \\
42.5 ?\end{array}$ & $\begin{array}{l}30.6 ? \\
61.5 ?\end{array}$ & $\begin{array}{l}21.7 \\
47.1\end{array}$ & $\begin{array}{l}25.3 ? \\
53.4 ?\end{array}$ & $\begin{array}{l}25.3 ? \\
53.4 ?\end{array}$ & $\begin{array}{c}24.4(23-28.2) \\
51.2(47.1-54.4)\end{array}$ \\
\hline $\begin{array}{l}\text { Head length } \\
\% \text { SL }\end{array}$ & $\begin{array}{l}17.2 \\
40.2\end{array}$ & $\begin{array}{l}18.2 \\
37.5\end{array}$ & $\begin{array}{l}16.7 \\
39.3\end{array}$ & $\begin{array}{l}22.5 \\
35 ?\end{array}$ & $\begin{array}{l}18.4 \\
37.0\end{array}$ & $\begin{array}{l}16.5 \\
35.8\end{array}$ & $\begin{array}{l}17.8 ? \\
37.9 ?\end{array}$ & $\begin{array}{l}18.4 ? \\
35.5 ?\end{array}$ & $\begin{array}{c}18.25(18.4-22.5) \\
37.9(35.8-40.2)\end{array}$ \\
\hline $\begin{array}{l}\text { Predorsal length } \\
\% \mathrm{SL}\end{array}$ & $\begin{array}{l}24.2 \\
56.6\end{array}$ & $\begin{array}{l}28.5 \\
56.8\end{array}$ & $\begin{array}{l}24.4 \\
57.5\end{array}$ & $\begin{array}{l}34.9 ? \\
54.3 ?\end{array}$ & $\begin{array}{l}28.2 \\
56.7\end{array}$ & $\begin{array}{l}25.8 \\
57.8\end{array}$ & $\begin{array}{l}27.6 ? \\
58.8 ?\end{array}$ & $\begin{array}{l}28.4 \\
54.8\end{array}$ & $\begin{array}{l}26.5(24.2-28.5) \\
56.7(54.8-57.8)\end{array}$ \\
\hline $\begin{array}{l}\text { Dorsal fin length } \\
\% \mathrm{SL}\end{array}$ & $\begin{array}{c}7.0 \\
16.3\end{array}$ & $\begin{array}{c}8.2 \\
16.3\end{array}$ & $\begin{array}{c}6.5 \\
15.3\end{array}$ & $\begin{array}{l}9.5 ? \\
16.2 ?\end{array}$ & $\begin{array}{c}7.4 \\
14.8\end{array}$ & $\begin{array}{c}8.0 \\
17.3\end{array}$ & $\begin{array}{c}7.6 \\
16.2 ?\end{array}$ & $\begin{array}{l}8.3 \\
17\end{array}$ & $\begin{array}{c}7.4(6.7-8.3) \\
16.1(14.8-17.3)\end{array}$ \\
\hline $\begin{array}{l}\text { Prepelvic length } \\
\% \text { SL }\end{array}$ & $\begin{array}{c}25.2 \\
59\end{array}$ & $\begin{array}{l}30.3 \\
60.4\end{array}$ & $\begin{array}{l}25.2 \\
59.4\end{array}$ & $\begin{array}{c}35 ? \\
54.5 ?\end{array}$ & $\begin{array}{l}29.6 \\
60.2\end{array}$ & $\begin{array}{l}26.6 \\
57.8\end{array}$ & $\begin{array}{c}26 ? \\
55.4 ?\end{array}$ & $\begin{array}{l}29.4 \\
56.8\end{array}$ & $\begin{array}{l}27.7(25.2-30.3) \\
58.9(56.8-60.4)\end{array}$ \\
\hline $\begin{array}{l}\text { Preanal length } \\
\% \mathrm{SL}\end{array}$ & $\begin{array}{l}33.7 \\
78.9\end{array}$ & $\begin{array}{l}38.5 \\
76.8\end{array}$ & $\begin{array}{l}33.4 \\
78.7\end{array}$ & $\begin{array}{l}52.6 ? \\
81.9 ?\end{array}$ & $\begin{array}{l}40.0 \\
80.4\end{array}$ & $\begin{array}{l}35.3 \\
76.7\end{array}$ & $\begin{array}{l}37.5 ? \\
79.9 ?\end{array}$ & $\begin{array}{l}42.2 \\
81.4\end{array}$ & $\begin{array}{l}37.1(33.4-42.2) \\
78.8(76.7-81.4)\end{array}$ \\
\hline $\begin{array}{l}\text { Anal fin length } \\
\% \mathrm{SL}\end{array}$ & $\begin{array}{c}8.1 \\
18.9\end{array}$ & $\begin{array}{c}8.3 \\
16.5\end{array}$ & $\begin{array}{c}7.3 \\
17.2\end{array}$ & $\begin{array}{c}10.9 \\
16.9 ?\end{array}$ & $\begin{array}{c}8.5 \\
17.1\end{array}$ & $\begin{array}{c}8.4 \\
18.2\end{array}$ & $\begin{array}{c}7.8 \\
15.3 ?\end{array}$ & $\begin{array}{l}? \\
?\end{array}$ & $\begin{array}{c}8.5(7.3-10.9 \\
17.5(16.5-18.9)\end{array}$ \\
\hline & & & & & Meristics & & & & Mode (Range) \\
\hline Total vertebrae & 35 & 33 & 34 & 34 & 35 & 35 & $33+$ & $29+$ & $34(33-35)$ \\
\hline Abdominal centra & 17 & 16 & 15 & 16 & 16 & 16 & $14+$ & $10+$ & $16(15-17)$ \\
\hline Caudal centra & 16 & 15 & 17 & 16 & 17 & 17 & 17 & 17 & $17(15-17)$ \\
\hline Pair of ribs & 14 & 15 & 15 & 15 & 14 & 14 & 15 & $?$ & $14-15$ \\
\hline Predorsal scutes & 8 & $5+$ & $7 ?$ & $3+$ & $3+$ & $4+$ & $5+$ & $3+$ & 8 \\
\hline Abdominal scutes & $22 ?$ & 23 & 22 & $18+$ & $22 ?$ & $21+$ & 23 & $5+$ & $23(22-23)$ \\
\hline Prepelvic scutes & $16 ?$ & 17 & 16 & $12+$ & $16 ?$ & $15+$ & 17 & $5+$ & $17(16-17)$ \\
\hline Postpelvic scutes & 6 & 6 & 6 & 6 & 6 & 6 & 6 & $?$ & 6 \\
\hline Dorsal fin rays & ii, 11 & $\mathrm{i}, 11$ & ii, 11 & $\mathrm{ii}, ?$ & ii, 9 ? & $\mathrm{ii}, 13$ & ii, 11 & $\mathrm{ii}, 11$ & ii,11 (i-ii,11-13) \\
\hline Dorsal pts. & 11 & 11 & 11 & 11 & $10+$ & 12 & $9+$ & $?$ & $11(11-12)$ \\
\hline Anal fin rays & ii, 17 & ii, 15 & ii, 17 & ii, 17 & I, $14 ?$ & ii, 17 & $?, 5+$ & ii, $17 ?$ & ii, 17 (ii, 15-17) \\
\hline Anal pts. & 17 & 15 & 16 & 15 & $14+$ & 17 & $14+$ & $12+$ & $17(16-18)$ \\
\hline Pectoral fin rays & 15 & 15 & $14+$ & $13+$ & 14 & $5+$ & 14 & 15 & $15(14-15)$ \\
\hline Pelvic fin rays & 6 & 5 & 5 & 5 & $5 ?$ & 5 & 7 & $6+$ & $5(5-7)$ \\
\hline Predorsal bones & 6 & 6 & 6 & 6 & 6 & 6 & 6 & $5 ?$ & 6 \\
\hline
\end{tabular}

Ortega et al. (2007); the specimens studied here have phosphatized masses forming whitish and soapy patches preserved in different parts of the body. These patches have a null reaction in acid solutions and under UV light are faint pink in color. In the trunk, these patches, mainly at the back and base of the unpaired fins, are muscle tissues. Beneath the opercular bones, there are phosphatized gill rakers and filaments. And into the abdominal cavity, these phosphatized materials form bumps along the digestive tract, from the back of the pelvic girdle to the anus. The abdominal cavity of IGM 11541 preserves isolated bones and the pelvic fins of a small fish. Although it is impossible to identify the species of such a swallowed fish; this observation demonstrates that Armigatus carrenoae sp. nov. fed on smaller fishes. 


\section{DISCUSSION}

\section{Comparative Remarks}

The morphological features of Armigatus carrenoae sp. nov. described here unambiguously show that this is a member of the superorder Clupeomorpha, order Ellimmichthyiformes, and family Armigatidae. The Clupeomorpha clade is well supported by the occurrence of three synapomorphies, the abdominal scute series covering the belly, from the isthmus to the anus, the otophysic connection on the skull, and the supratemporal commissural sensory canal passing through the parietals, or through the parietals and supraoccipital (i.e. Greenwood et al., 1966; Patterson and Rosen, 1977; Grande, 1985; Arratia, 1997; among others). Armigatus carrenoae is a true clupeomorph because it has the abdominal scute series and the supratemporal commissure on the parietals (Figures $3-5,8)$.

Grande (1982) erected the family Ellimmichthyidae and subsequently, he reranked its taxonomical hierarchy to order Ellimmichthyiformes (Grande, 1985). According to him, this order is supported by a single character, the presence of predorsal scutes that are subrectangular and laterally expanded. The importance of this feature has been declining in recent studies, after the inclusion of basal clupeomorph into this order, as Foreyclupea loonensis, Ranulfoichthys dorsonudum, and Codoichthys carnavalii (Figure 11), which either have no predorsal scutes or these are rather oval rather than rectangular (Murray and Wilson, 2013; Figueiredo and Ribeiro, 2016; Vernygora and Murray, 2016; Vernygora et al., 2016). Recent phylogenetic analyses recognize that the order Ellimmichthyiformes is supported by an exclusive mixture of characters, which includes: the mesoparietal condition of the skull, the basipterygoid process in the parasphenoid, the beryciform foramen piercing the anterior ceratohyal, the occurrence of three epineurals, and the presence of a predorsal scute series (see, Murray and Wilson, 2013; Murray et al, 2016; Vernygora and Murray, 2016; among others). Since Armigatus carrenoae sp. nov. has a series of predorsal triangular scutes, as well as, all the characters of the mixture described above, this species is a member of the order Ellimmichthyiformes.

The family Armigatidae was erected by Murray and Wilson (2013) to include Armigatus and Diplomystus (also see Murray et at., 2016; Vernygora and Murray, 2021); however, this group has not been recovered in some of the latest phyloge- netic hypotheses (Vernygora and Murray, 2016; Marramà and Carnevale, 2016; Figueiredo and Ribeiro, 2016, 2017; Boukhalfa et al., 2019; Marramà et al., 2019) (Figure 11). According to Murray and Wilson (2013), this family is unified by two putative synapomorphies, the distal end of uroneural 2 reaches the distal end of the uroneural 1 , and the third hypural is posteriorly expanded and leaves no gap between the hypurals 2 and 3 . Both features are present in Armigatus carrenoae sp. nov. supporting its inclusion in this family (Figure 9).

To date, the Ellimmichthyiformes comprises at least 45 nominal species gathered in 22 genera, which were described as part of or at least once included in the phylogenetic assays of this order (Figure 11, Table 2). A brief morphological comparison of the specimens described here reveals that Armigatus carrenoae sp. nov. belongs to Armigatus. These ellimmichthyiforms include fusiform and deep-bodied species that have none, one, two, or three scute series bordering the trunk (the abdominal, predorsal, and postdorsal series). Ornategulum sardinoides differs from all ellimmichthyiforms, including $A$. carrenoae sp. nov., mainly because it has no scutes bordering the trunk. Although Vernygora et al. (2016) and Marramà et al. (2019) concluded that Ornategulum is a basal ellimmichthyiform based on the presence of the mesoparietal condition of the skull and the lack of the recessus lateralis (Figure 11), other authors have considered this fusiform fish is an incertae sedis species of the order Clupeiformes (Forey, 1973) or even a non-clupeomorph (ZaragüetaBagils 2002, 2004; Alvarado-Ortega et al., 2008; Boukhalfa et al., 2019).

Armigatus carrenoae sp. nov. exhibits the emblematic deep body observed in most double and triple armored ellimmichthyiforms, which is easily distinguishable from those gracile fusiformlike species that only have the abdominal scute series, such as Ranulfoichthys dorsonudum and Foreyclupea loonensis, or from those that have the abdominal and predorsal series, such as Scutatuspinosus itapagipensis and Codoichthys carnavalii. This new Mexican species is also easily differentiable from the triple armored ellimmichthyiforms, as Triplomystus and Scutatoclupea, which include four species that own three scute series, the abdominal, predorsal, and postdorsal (see Forey et al., 2003; Alvarado-Ortega and Ovalles-Damián, 2008; Bannikov, 2015).

Armigatus carrenoae sp. nov. only has the abdominal and predorsal scute series, like all other 
Alvarado-Ortega, Than-Marchese, \& del Pilar Melgarejo-Damián: Albian Armigatus in America
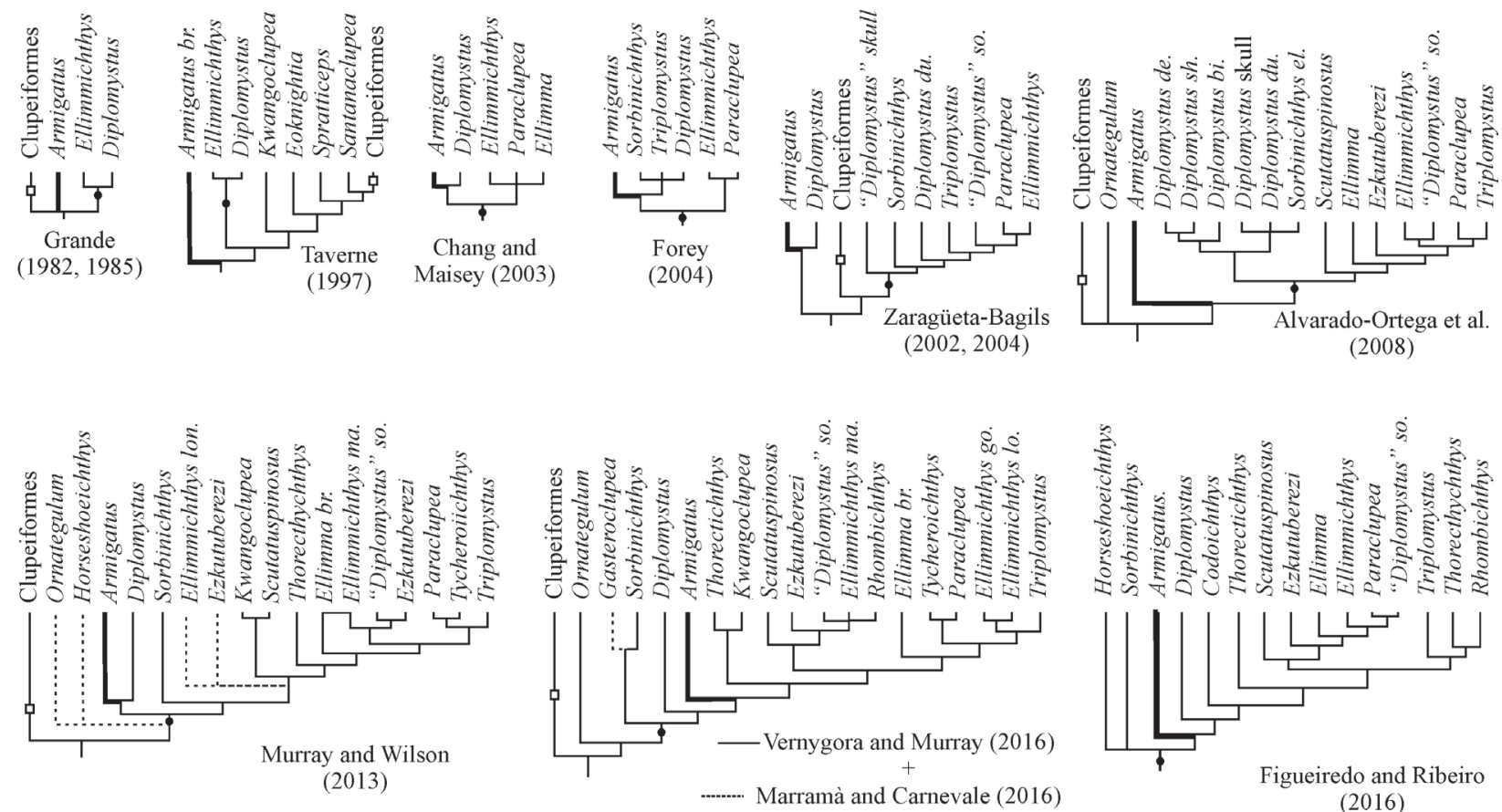

(2016)

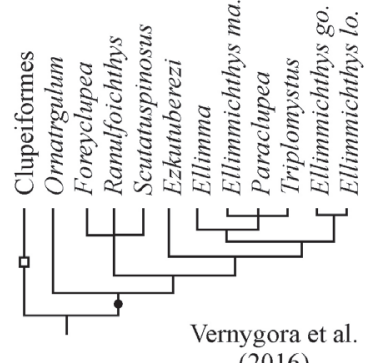

(2016)

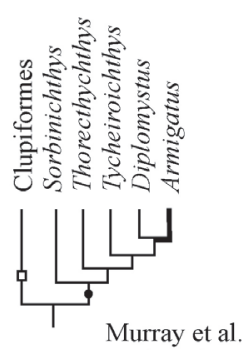

(2016)

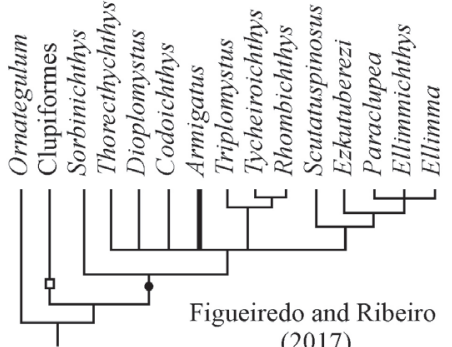

(2017)
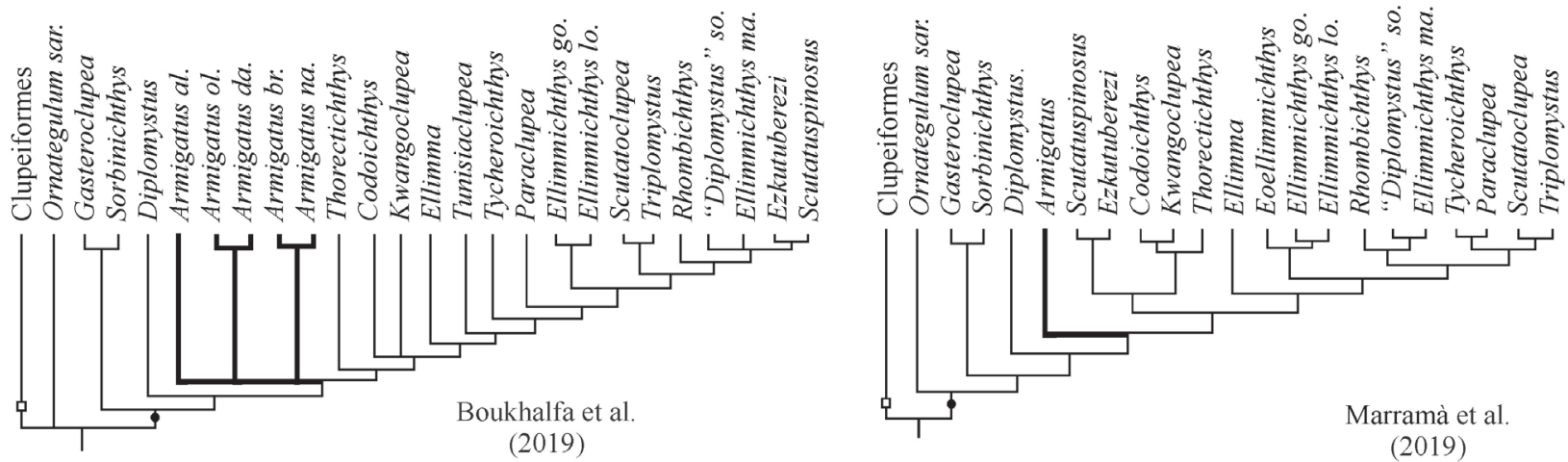

FIGURE 11. Phylogenetic hypotheses of Ellimmichthyiformes that show the different positions of Armigatus (dark lines) and members of this order (dark circle) and Clupeiformes (white square). 
TABLE 2. Nominal species currently included in the order Ellimmichthyiformes (continued on next page).

\begin{tabular}{|c|c|}
\hline Species & Age and Distribution \\
\hline Armigatus alticorpus Forey, Yi, Patterson, and Davies, 2003. & Cenomanian. Namoura, Lebanon. \\
\hline Armigatus brevissimus (Blainville, 1818). & Cenomanian. Heckel and Hajula, Lebanon. \\
\hline Armigatus carrenoae sp. nov. (present manuscript). & Albian. Tlayúa quarry, Mexico. \\
\hline $\begin{array}{l}\text { Armigatus dalmaticus Murray, Vernygora, Japundžić, Radovčić, Wilson, } \\
\text { Bardack, and Grande, } 2016 .\end{array}$ & Campanian? Dalmatia, Croatia. \\
\hline Armigatus namourensis Forey, Yi, Patterson, and Davies, 2003. & Cenomanian. Namoura, Lebanon. \\
\hline Armigatus oligodentatus Vernygora and Murray, 2016. & Cenomanian/Turonian. Agoult, Morocco. \\
\hline Codoichthys carnavalii Silva Santos, 1994. & Aptian. São Luís-Grajaú Basin, Brazil. \\
\hline Diplomystus altisomus Yabumoto, 1994. & Early Cretaceous. Kyushu, Japan. \\
\hline Diplomystus birdi Woodward, 1895. & Cenomanian. Heckel and Hajula, Lebanon. \\
\hline Diplomystus dentatus Cope, 1877. & Eocene. Green River Fm., USA. \\
\hline Diplomystus dubertreti Signeux, 1951. & Santonian. Sahel Alma, Lebanon. \\
\hline Diplomystus kokuraensis Uyeno, 1979. & Neocomian. Kyushu, Japan. \\
\hline Diplomystus primotinus Uyeno, 1979. & Neocomian. Kyushu, Japan. \\
\hline Diplomystus solignaci Gaudant and Gaudant, 1971. & Senonian. Gabès, Tunisia. \\
\hline Diplomystys shengliensis Zhang, Zhou, and Qing, 1985. & Eocene. Shandong, China. \\
\hline "Diplomystus" trebicianensis Bannikov and Sorbini, 2000. & Paleocene, Trebiano, Italy. \\
\hline Ellimma branneri (Jordan, 1910). & Hauterivian-Aptian. Muribeca Fm., Brazil. \\
\hline Ellimma cruzi Silva Santos 1990. & Aptian. Cabo Fm., Brazil. \\
\hline $\begin{array}{l}\text { Ellimma longipectoralis Polck, Gallo, Figueiredo, Viana, Santos, Quiroz- } \\
\text { Neto, and Jahnert, } 2020 .\end{array}$ & Aptian. Velha Fm., Santos Basin, Brazil. \\
\hline Ellimmichthys longicostatus (Cope, 1886). & Hauterivian-Barremian. Recôncavo Fm., Brazil. \\
\hline Ellimmichthys goodi Eastman, 1912. & $\begin{array}{l}\text { Aptian-Albian. Cocobeach Series, Equatorial } \\
\text { Guinea. }\end{array}$ \\
\hline $\begin{array}{l}\text { Ellimmichthys maceioensis Malabarba, Do Carmo, Gómez-Pérez, and } \\
\text { Queiroz-Neto, } 2004 .\end{array}$ & Aptian-Albian. Maceio Fm., Brazil. \\
\hline $\begin{array}{l}\text { Eoellimmichthys superstes Marramà, Bannikov, Kriwet, and Carnevale, } \\
2019 .\end{array}$ & Early Eocene. Pesciara, Italy. \\
\hline $\begin{array}{l}\text { Ezkutuberezi carmenae (Poyato-Ariza, López-Horgue, and García- } \\
\text { Garmilla, 2000). }\end{array}$ & Valanginian-Barremian. Villaro Fm., Spain. \\
\hline Foreyclupea loonensis Vernygora, Murray and Wilson, 2016. & Albian. Loon River Fm., Canada. \\
\hline
\end{tabular}

members of the unnatural ellimmichthyiform group composed of double-armored herrings. In these fishes, the predorsal scutes show distinctive features, often with diagnostic value (Grande, 1982, 1985; Chang and Grande, 1997, Chang and Maisey, 2003; among others). The predorsal scutes of $A$. carrenoae and $A$. brevissimus are subtriangular or heart-shaped, have smooth borders, and exhibit inconspicuous superficial ornamentation. In Ellimma, Ellimmichthys, Triplomystus, and Tycheroichthys these scutes are more laterally expanded, becoming subrectangular, preserve the smooth borders, and are strongly ornamented with ridges and tubercles. In Diplomystus the predorsal scutes are highly distinctive; these are subrectangular, antero-posteriorly shorth and extremely lat- erally expanded, smooth, and have a strongly serrated posterior border. Other genera show predorsal scutes with different combinations of these features, as in Sorbinichthys, Kwangoclupea, and Tunisiaclupea (e.g., Taverne, 1997; Bannikov and Bacchia, 2000; Murray and Wilson, 2011; Boukhalfa et al., 2019). As Grande (1982, 1985) stated, Armigatus differs from other ellimmichthyiforms in the presence of an incomplete predorsal scute series. Armigatus carrenoae sp. nov. shares this feature (Figure 10).

Armigatus was erected by Grande (1982, p. 4 ), based on a single species, $A$. brevissimus (Figures 1,12) and its original diagnosis included the following features: 1) the osteoglossid-like tooth patch on the parasphenoid; 2) the parietals are in 
TABLE 2 (continued).

\begin{tabular}{|c|c|}
\hline Species & Age and Distribution \\
\hline $\begin{array}{l}\text { Gateroclupea branisai Signeux, } 1964 \text { (see Marramà and Carnevale, } \\
\text { 2017) }\end{array}$ & Late Cretaceous-Paleocene. Cayara, Bolivia. \\
\hline $\begin{array}{l}\text { Horseshoeichthys armaserratus Newbrey, Murray, Brinkman, Wilson, } \\
\text { and Neuman, } 2010 .\end{array}$ & Maastrichtian. Horseshoe Canyon Fm., Canada. \\
\hline Kwangoclupea dartevellei (Casier, 1965). & Cenomanian. Kwango, Zaire. \\
\hline Ornategulum sardinoides (Pictet, 1850). & Cenomanian. Heckel and Hajula, Lebanon. \\
\hline Paraclupea chetungensis Sun, 1956. & Early Cretaceous. Chawan Fm., China. \\
\hline Paraclupea seilacheri Alvarado-Ortega and Melgarejo-Damián, 2017. & Albian. Tlayúa, Mexico. \\
\hline Ranulfoichthys dorsonudum Alvarado-Ortega, 2014. & Albian. Tlayúa, Mexico. \\
\hline $\begin{array}{l}\text { Rhombichthys intoccabilis Khalloufi, Zaragüeta-Bagils, and Lelièvre, } \\
2010 .\end{array}$ & Cenomanian. Ein Yabrud, Palestine. \\
\hline Scutatoclupea bacchiai Bannikov, 2015. & Cenomanian. Namoura, Lebanon. \\
\hline Scutatuspinosus itapagipensis Santos and Corrêa, 1985. & Hauterivian?. Marfim Fm., Brazil. \\
\hline Sorbinichthys elusive Bannikov and Bacchia, 2000. & Cenomanian. Namoura, Lebanon. \\
\hline Sorbinichthys africanus Murray and Wilson, 2011. & Cenomanian/Turonian. Agoult, Morocco. \\
\hline Thorectichthys rhadinus Murray and Wilson, 2013. & Cenomanian/Turonian. Agoult, Morocco. \\
\hline Thorectichthys marocensis Murray and Wilson, 2013. & Cenomanian/Turonian. Agoult, Morocco. \\
\hline Triplomystus applegatei Alvarado-Ortega and Ovalles-Damián, 2008. & Cenomanian. El Espinal, Mexico. \\
\hline Triplomystus noorae Forey, Yi, Patterson, and Davies, 2003. & Cenomanian. Namoura, Lebanon. \\
\hline Triplomystus oligocostatus Forey, Yi, Patterson, and Davies, 2003. & Cenomanian. Namoura, Lebanon. \\
\hline Tycheroichthys dunveganensis Hay, Cumbaa, Murray, and Plint, 2007. & Cenomanian. Dunvegan Fm., Canada. \\
\hline Tunisiaclupea speratus Boukhalfa, Wu, Ben Ali, and Fang, 2019. & Late Barremian. Chotts Basin, Tunisia. \\
\hline
\end{tabular}

contact with each other, between the supraoccipital and frontals; 3) a large beryciform foramen in the anterior ceratohyal; 4) subtriangular predorsal scutes; 5 ) the predorsal scutes form a series that extends only over two-thirds of the distance between the occiput and dorsal fin base (this con- dition is hereby referred to "the incomplete predorsal scute series"). After the inclusion of $A$. naumourensis and $A$. alticorpus in this genus, Forey et al. (2003, p. 275) emended this diagnosis to include the presence of the following additional features: 6) medial surface of entopterygoid with
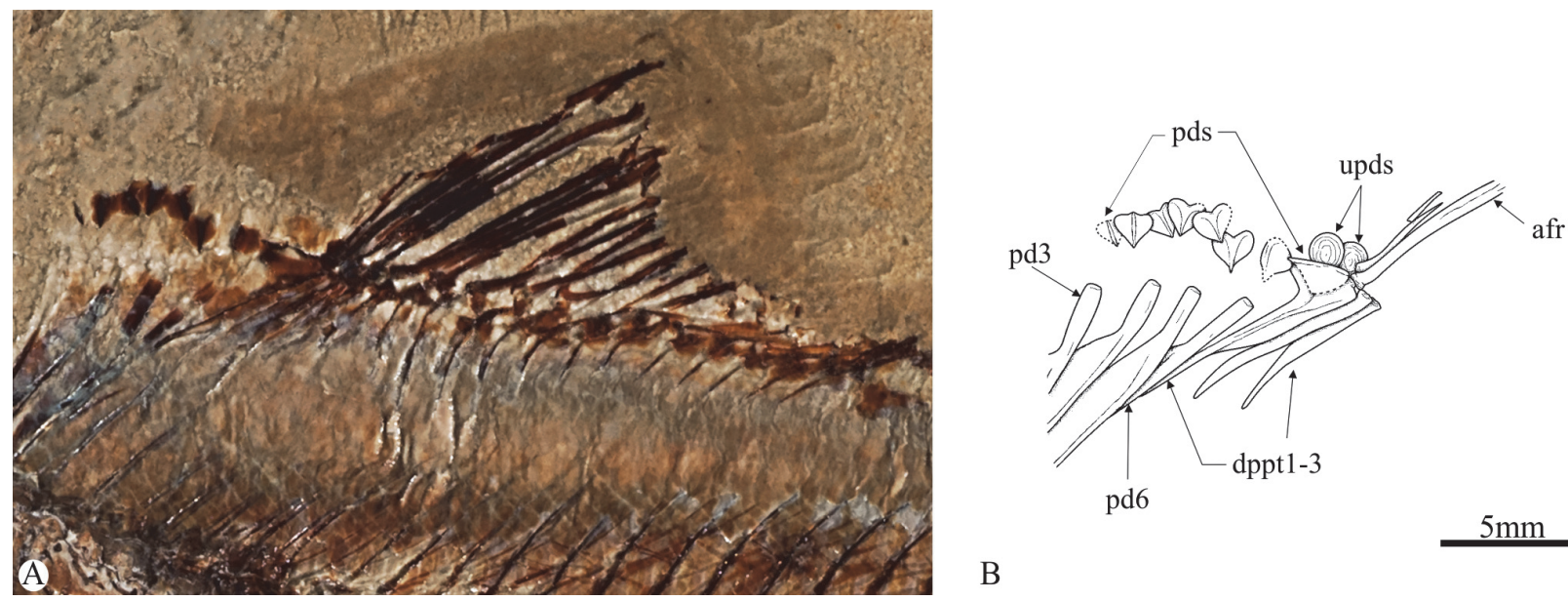

B

FIGURE 12. Dorsal region of Armigatus brevissimus. A, closeup of the specimen IGM 11532 from the Cenomanian shallow marine deposits of Hekel, Lebanon, under white light. B, idealized and simplified drawing of predorsal scutes and near bones based on A. Abbreviations: afr, anal fin ray; pd, predorsal bone; pds, predorsal scutes; dppt, dorsal proximal pterygiophore; upds, unmodified predorsal scales. 
enlarged teeth; 7) dorsal and ventral hypohyals much deeper than long; 8) parietals carrying the supratemporal commissure within a bone-enclosed tube; 9) the base of the posterior border of the posttemporal bone is crenulated; 10) proximal radials of posterior eight or so pterygiophores in dorsal fin with expanded heads. Unfortunately, characters 1-3 and 6-8 are not exclusive to Armigatus and have been documented in other ellimmichthyiform taxa; hence, individually these have poor diagnostic value. The crenulated posterior edge of the posttemporal bone described by Forey et al. (2003) (feature 9) is not exclusive of Armigatus because it is also present in Paraclupea seilacheri (AlvaradoOrtega and Melgarejo-Damián, 2017, figure 6); in any case, $A$. carrenoae also has a posttemporal bone with a crenulated posterior edge (Figure 5). The diagnostic usefulness of features 7 and 10 is at least questionable because Forey et al. (2003) did not provide a broader and accurate discussion; however, $A$. carrenoae can be definitively said to possess these (Figures 5,8 ). In the present context, the most compelling diagnostic feature of Armigatus is the presence of subtriangular predorsal scutes forming an incomplete series (features 4 and 5). A.carrenoae sp. nov. is a member of Armigatus because it possesses the features 4 and 5 , as well as 1-6 and 8-9 (Figures 3-10).

Table 3 summarizes a comparison of the morphological features present in the nominal species already included within Armigatus. The body proportions of these species are similar except for the body height; $A$. oligodentatus is a comparatively gracile and elongated fish, in which the maximum body height is close to $32.1 \%$ of SL, whereas Armigatus carrenoae sp. nov. and other species have higher bodies (the maximum body heights range between 37.2 and $51.2 \%$ of SL). In addition, A. carrenoae shares a relatively low number of anal and dorsal fin rays (15-17 and 11-13, respectively) with $A$. dalmaticus (16 and 13-14) and probably with $A$. oligodentatus (12?-14? and 10?-13?). In contrast, these fins have more rays in $A$. brevissimus (28 and 19), A. namourensis (24-27 and 1819 ), and $A$. alticorpus (at least 25 ? and 15-17). In $A$. namourensis and $A$. alticorpus, there are five to six predorsals while in $A$. carrenoae and $A$. brevissimus there are always 6 of these bones. Contrastingly, $A$. oligodentatus and $A$. dalmaticus have seven to eight predorsal bones. Moreover, the number of total vertebrae is variable among Armigatus species: $A$. brevissimus only has $31 ; A$. dalmaticus and $A$. carrenoae share an intermediate condition in which this number ranges between 33-
35 and 32-37, respectively, and $A$. namourensis, $A$. alticorpus, and $A$. oligodentatus have more vertebrae, between 37 and 38 . Finally, A. carrenoae has only six postpelvic scutes while $A$. brevissimus has seven and other species have eight to 11 .

Other osteological features that highlight the uniqueness of $A$. carrenoae sp. nov. seem to be somewhat problematic (Table 3). On the one hand, this Mexican species, $A$. brevissimus, and $A$. namourensis show the osteoglossid-like tooth patch in the parasphenoid bone. Remarkably, this structure has not been observed in A. oligodentatus, A. dalmaticus, and $A$. alticorpus (Forey et al., 2003; Murray et al., 2016, Vernygora and Murray, 2016; Vernygora and Murray, 2021). On the other hand, in $A$. brevissimus, $A$. namourensis, and $A$. carrenoae sp. nov. the frontal, parietal, and pterotic bones are strongly ornamented with conspicuous grooves and sinuous ridges that enclose the paths of the preorbital, temporal, and supratemporal canals, which open through some pores scattered on the surface of these bones (Figure 5). Similar ornamentation of such bones is present in other ellimmichthyiforms, as Ellimmichthys, Ellimma, and Paraclupea (Chang and Grande, 1997, figure 4). In contrast, bones of the skull roof are smooth in $A$. alticorpus, $A$. oligodentatus, and $A$. dalmaticus (Vernygora and Murray, 2016, 2021; Murray et al., 2016, figure 2). Additionally, at least $A$. carrenoae sp. nov. and $A$. brevissimus share the presence of short apicobasal grooves on the basal quarter of the opercular surface (Figures 1, 4, 6). A similar opercular ornamentation is also present other deep-bodied ellimmichthyiformes, such as Ellimmichthys branneri and Paraclupea seilacheri (Chang and Maisey, 2003, figure 4; AlvaradoOrtega and Melgarejo-Damián, 2017, figure 5). Otherwise, the opercle seems to be superficially smooth in $A$. oligodentatus, $A$. dalmaticus, and $A$. alticorpus (Murray et al., 2016; Vernygora and Murray, 2016, 2021). These opercular grooves are unclear in A. namourensis (Forey et al., 2003).

Besides Armigatus carrenoae sp. nov., both $A$. brevissimus and $A$. alticorpus also have epineurals and epipleurals associated with all centra except for the posteriormost four preurals. Hence, the most posteriors of these elongated bones almost reach the caudal peduncle (Figures 3, 4, 9, Table 3). A similar distribution of these bones seems to be present in all the species of Diplomystus and Gasteroclupea branisai (Grande, 1982; Chang and Maisey, 1997, figure 12.A; Marramà and Carnevale, 2017, figure 5.D). In A. naumorensis, $A$. oligodentatus, and $A$. dalmaticus the epi- 
TABLE 3. Comparison of the nominal species of the genus Armigatus. Maximum standard length (SL) expressed in millimeters, (based on data from table 3; Forey et al., 2003; Murray et al., 2016, tables 2, 3; Vernygora and Murray, 2016 , table 1; Vernygora and Murray, 2021).

\begin{tabular}{|c|c|c|c|c|c|c|c|}
\hline \multicolumn{2}{|c|}{$\begin{array}{c}\text { Species } \rightarrow \\
\text { Number of individuals } \\
\text { considered } \rightarrow\end{array}$} & $\begin{array}{c}\text { Armigatus } \\
\text { carrenoae sp. } \\
\text { nov. } \\
\text { (8) }\end{array}$ & $\begin{array}{c}\text { Armigatus } \\
\text { brevissimus } \\
\text { (10) }\end{array}$ & $\begin{array}{c}\text { Armigatus } \\
\text { namouraensis } \\
(11)\end{array}$ & $\begin{array}{l}\text { Armigatus } \\
\text { alticorpus } \\
\text { (6) }\end{array}$ & $\begin{array}{c}\text { Armigatus } \\
\text { oligodentatus } \\
\text { (8) }\end{array}$ & $\begin{array}{c}\text { Armigatus } \\
\text { dalmaticus } \\
\text { (6) }\end{array}$ \\
\hline \multirow{6}{*}{ 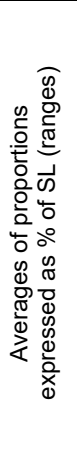 } & Maximum TL & $\approx 81.9$ & 105 & 139 & 47 & 37 & 48.6 \\
\hline & Body height & $\begin{array}{c}51.2 \\
(47.1-54.4)\end{array}$ & $\begin{array}{c}37.3 \\
(33-42)\end{array}$ & $\begin{array}{c}37.7 \\
(31-50)\end{array}$ & $\begin{array}{c}48.9 \\
(46.1-52.7)\end{array}$ & $\begin{array}{c}32.1 \\
(28-36)\end{array}$ & $\begin{array}{c}40.8 \\
(34.6-44-8)\end{array}$ \\
\hline & Head length & $\begin{array}{c}37.9 \\
(35.8-40.2)\end{array}$ & $\begin{array}{c}33.6 \\
(30-38)\end{array}$ & $\begin{array}{c}31.9 \\
(28-35)\end{array}$ & $\begin{array}{c}34.2 \\
(33.3-36.1)\end{array}$ & $\begin{array}{c}32.5 \\
(31-35)\end{array}$ & $\begin{array}{c}31.3 \\
(28-33)\end{array}$ \\
\hline & Predorsal length & $\begin{array}{c}56.7 \\
(54.8-57.8)\end{array}$ & $\begin{array}{c}46.5 \\
(44-49)\end{array}$ & $\begin{array}{c}47.3 \\
(43-52)\end{array}$ & $\begin{array}{c}49.2 \\
(47.9-51)\end{array}$ & $\begin{array}{c}48.6 \\
(46-52)\end{array}$ & $\begin{array}{c}46.3 \\
(43.3-50.2)\end{array}$ \\
\hline & Preanal length & $\begin{array}{c}78.8 \\
(76.7-81.4)\end{array}$ & $\begin{array}{c}67.1 \\
(64-72)\end{array}$ & $\begin{array}{c}69.1 \\
(66-77)\end{array}$ & $\begin{array}{c}69.9 \\
(66.6-73.7)\end{array}$ & $\begin{array}{c}77.8 \\
(75-82)\end{array}$ & $\begin{array}{c}75.4 \\
(66.5-81.9)\end{array}$ \\
\hline & Prepelvic length & $\begin{array}{c}58.9 \\
(56.8-60.4)\end{array}$ & $\begin{array}{c}50 \\
(47-56)\end{array}$ & $\begin{array}{c}51.5 \\
(49-56)\end{array}$ & $\begin{array}{c}53.6 \\
(55.5-50)\end{array}$ & $\begin{array}{c}55.2 \\
(50-58)\end{array}$ & $\begin{array}{c}56.4 \\
(55.4-57.8)\end{array}$ \\
\hline \multirow{11}{*}{ 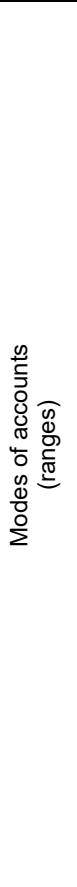 } & Anal fin rays & $\begin{array}{c}\mathrm{ii}, 17 \\
(\mathrm{ii}, 15-17)\end{array}$ & $\begin{array}{c}28 \\
-\end{array}$ & $\begin{array}{c}25 \\
(24-27)\end{array}$ & $\begin{array}{c}25+ \\
(?-25+)\end{array}$ & $\begin{array}{c}? \\
(12 ?-14 ?)\end{array}$ & $\begin{array}{c}16 \\
-\end{array}$ \\
\hline & Dorsal fin rays & $\begin{array}{c}\mathrm{ii}, 11 \\
(\mathrm{i}-\mathrm{ii}, 11-13)\end{array}$ & $\begin{array}{l}19 \\
-\end{array}$ & $\begin{array}{c}19 \\
(18-19)\end{array}$ & $\begin{array}{c}16 \\
(15-17)\end{array}$ & $\begin{array}{c}11 \\
(10 ?-13 ?)\end{array}$ & $\begin{array}{c}13,14 \\
(13-14)\end{array}$ \\
\hline & Pectoral fin rays & $\begin{array}{c}15 \\
(14-15)\end{array}$ & $\begin{array}{c}20 \\
(18-20)\end{array}$ & $\begin{array}{c}12 \\
(12-15)\end{array}$ & $\begin{array}{c}12 \text { or } 13 ? \\
(12-13)\end{array}$ & $\begin{array}{c}8 \\
(8-13)\end{array}$ & $\begin{array}{c}? \\
(12-13)\end{array}$ \\
\hline & Pelvic fin rays & $\begin{array}{c}5 \\
(5-7)\end{array}$ & $\begin{array}{l}7 \\
-\end{array}$ & $\begin{array}{c}8 \\
(8-9)\end{array}$ & $\begin{array}{l}? \\
-\end{array}$ & $\begin{array}{c}7 \\
(6-9)\end{array}$ & $\begin{array}{c}7 ? \\
-\end{array}$ \\
\hline & Predorsal bones & $\begin{array}{c}6 \\
(6)\end{array}$ & $\begin{array}{c}6 \\
(6)\end{array}$ & $\begin{array}{c}6 \\
(5-6)\end{array}$ & $\begin{array}{c}6 \\
(5-6)\end{array}$ & $\begin{array}{c}8 \\
(7 ?-8)\end{array}$ & $\begin{array}{l}7,8 \\
(7-8)\end{array}$ \\
\hline & Total vertebrae & $\begin{array}{c}34 \\
(33-35)\end{array}$ & $\begin{array}{c}31 \\
(31-32)\end{array}$ & $\begin{array}{c}38 \\
(36-38)\end{array}$ & $\begin{array}{c}36 \text { or } 37 \\
(35-37)\end{array}$ & $\begin{array}{c}38 \\
(37-39)\end{array}$ & $\begin{array}{c}34 \\
(32-37)\end{array}$ \\
\hline & Abdominal & $\begin{array}{c}16 \\
(15-17)\end{array}$ & $\begin{array}{c}17 \\
(16-18)\end{array}$ & $\begin{array}{c}18 \\
(17-19)\end{array}$ & $\begin{array}{c}16 \\
(16-18)\end{array}$ & $\begin{array}{c}24 ? \\
(23-25)\end{array}$ & $\begin{array}{c}i \\
(14-19)\end{array}$ \\
\hline & $\begin{array}{l}\text { Caudal (including } \\
\text { urals) }\end{array}$ & $\begin{array}{c}19 \\
(17-19)\end{array}$ & $\begin{array}{c}15 \\
(13-15)\end{array}$ & $\begin{array}{c}20 \\
(17-21)\end{array}$ & $\begin{array}{c}20 \\
(19-21)\end{array}$ & $\begin{array}{c}14,15 \\
(14-15)\end{array}$ & $\begin{array}{c}18 \\
(13 ?-18)\end{array}$ \\
\hline & Predorsal scutes & $\begin{array}{c}8 \\
(8)\end{array}$ & $\begin{array}{c}9 \\
(9)\end{array}$ & $\begin{array}{c}17 \\
(17-19)\end{array}$ & $\begin{array}{c}11 ? \\
(7+-11 ?)\end{array}$ & $\begin{array}{c}? \\
(5 ?-9 ?)\end{array}$ & $\begin{array}{c}11 \\
(10-11)\end{array}$ \\
\hline & Prepelvic scutes & $\begin{array}{c}17 \\
(16-17)\end{array}$ & $\begin{array}{l}16 \\
-\end{array}$ & $\begin{array}{c}20 \\
(19-21)\end{array}$ & $\begin{array}{l}17 \\
-\end{array}$ & $\begin{array}{c}13 \\
(10-13)\end{array}$ & $\begin{array}{c}13 \\
(13)\end{array}$ \\
\hline & Postpelvic scutes & $\begin{array}{l}6 \\
(6)\end{array}$ & $\begin{array}{c}7 \\
(6 ?-7)\end{array}$ & $\begin{array}{c}8 \\
(8-9)\end{array}$ & $\begin{array}{c}7 \\
(7)\end{array}$ & $\begin{array}{l}10,11 \\
(8-11)\end{array}$ & $\begin{array}{l}9-10 \\
(9-10)\end{array}$ \\
\hline \multirow{6}{*}{ 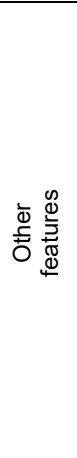 } & Skull roof bones & \multicolumn{3}{|c|}{$\begin{array}{l}\text { Stout ridges ornament the frontal, parietal, and } \\
\text { pterotic. }\end{array}$} & \multicolumn{3}{|c|}{ Smooth } \\
\hline & Parasphenoid & \multicolumn{3}{|c|}{ with the osteoglossid-like tooth patch } & $?$ & \multicolumn{2}{|c|}{ toothless } \\
\hline & $\begin{array}{l}\text { Opercle } \\
\text { ornaments }\end{array}$ & \multicolumn{2}{|c|}{ Basal short and straight grooves } & \multicolumn{2}{|l|}{$?$} & \multicolumn{2}{|c|}{ Smooth } \\
\hline & $\begin{array}{l}\text { Epineurals and } \\
\text { epipleurals }\end{array}$ & \multicolumn{2}{|c|}{ close to caudal peduncle } & $\begin{array}{l}\text { far from the } \\
\text { caudal peduncle }\end{array}$ & $\begin{array}{l}\text { close to caudal } \\
\text { peduncle }\end{array}$ & \multicolumn{2}{|c|}{ far from the caudal peduncle } \\
\hline & $\begin{array}{l}\text { Predorsal bones } \\
\text { below predorsal } \\
\text { scutes }\end{array}$ & \multicolumn{2}{|c|}{$\begin{array}{l}\text { Posterior } 4-3(=\text { predorsal series } \\
\text { inccomplete }\end{array}$} & $\begin{array}{l}\text { All (= predorsal } \\
\text { series complete) }\end{array}$ & Posterior 4 & $?$ & $\begin{array}{c}\text { All (= predorsal } \\
\text { series } \\
\text { complete) }\end{array}$ \\
\hline & Posterior & Posterior ones & Posterior ones & All are heart- & All are wide & All are heart- & All \\
\hline
\end{tabular}



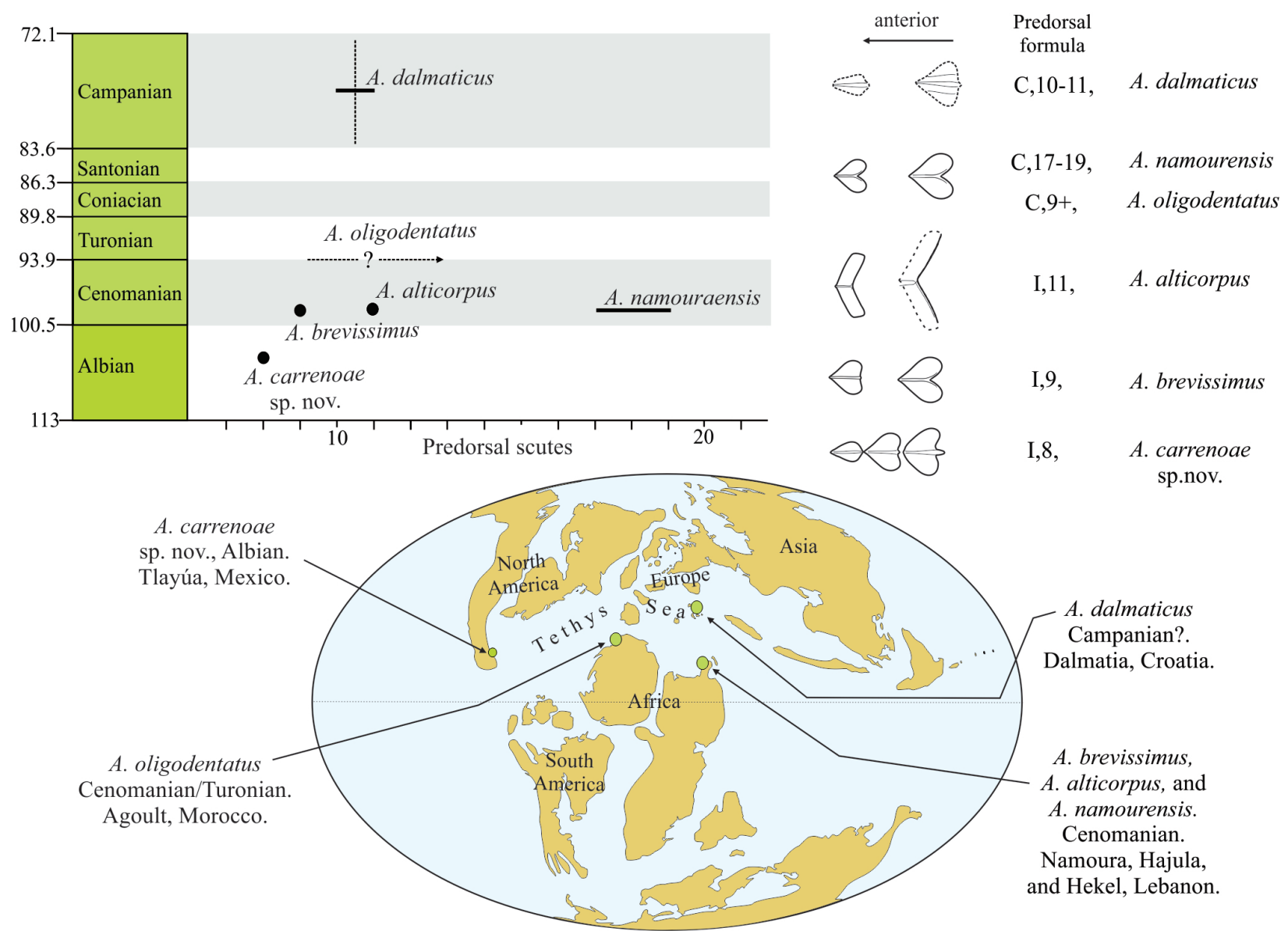

FIGURE 13. Paleobiographical distribution and diversity of predorsal scutes of Armigatus. Abbreviations in the predorsal scute formula: C, complete predorsal scute series; I, incomplete predorsal scute series; the number of predorsal scutes in each species is shown in front of the draws; draws show the change in the shape of the scutes along the predorsal observed in species; light arrows point to posterior scutes; dark arrows show the hypothetic intraspecific change of the predorsal scutes.

neurals and epipleurals are present only in the most anterior caudal centra, far from the caudal peduncle, and in extreme cases only are extended as far as the anal fin (Forey et al., 2003, figure 54; Vernygora and Murray, 2016, figure 1; Murray et al., 2016, figure 1).

Finally, Armigatus carrenoae sp. nov. differs from other species of Armigatus because its predorsal scute series has anterior oval scutes, which progressively are more expanded and change to a subtriangular-shape; here, the posterior predrosal scute is the biggest and has a conspicuous posterior spine (Figure 10, 13, Table 3). In Armigatus brevissimus, the anterior predorsal scutes are subtriangular while the posteriormost predorsal scutes are heart-shaped and have no posterior spine (Figure 12; Grande, 1982, 1985). In A. namourensis and $A$. oligodentatus, the predorsal scutes seem to be uniformly heart-shaped (Forey et al., 2003; Murray et al., 2016). Armigatus alticorpus and A. dal- maticus own the most distinctive and intriguing predorsal scutes; in the former species, these scutes are evenly subrectangular, antero-posteriorly short, extremely laterally expanded, and have no posterior spine (Vernygora and Murray, 2021, figures 7.A and 7.B) while in the latter species, such scutes are rather subrectangular, a little laterally expanded, and most of them have a posterior spine (Murray et al., 2016, figure 2).

Furthermore, in Armigatus carrenoae sp. nov., $A$. brevissimus, and $A$. alticorpus the space occupied by the predorsal scute series shows and additional distinctive condition (Table 3); the comparatively low number of predorsal cutes ( 8 to 9) forms a true incomplete predorsal series, which is preceded by unmodified scales and lies close to the dorsal tips of the posterior three or four predorsal bones (Figures, 10, 12, 13; Vernygora and Murray, 2021, figure 7). In other species of this genus, the number and distribution of predorsal scutes 
resemble those of the complete predorsal scute series observed in other ellimmichthyiforms, such as Ellimma, Ellimmichthys, and Paraclupea (Chang and Grande, 1997; Chang and Maisey, 2003; Alvarado-Ortega and Melgarejo-Damián, 2017; among others). Armigatus namouraensis, $A$. dalmaticus, and probably $A$. oligodentatus have more predorsal scutes (10 to 19$)$ that cover a larger portion of the predorsal edge of the trunk, lie over all the predorsal bones, and reach a position closer to the occiput (see Forey et al., 2003, figures 51.A, 54; Murray et al., 2016, figure 2; Vernygora and Murray, 2016, figure 1).

\section{Biogeographical Remarks}

Paleontological researches in Mexico of the last 20 years have allowed the recovery of numerous fossils of clupeomorph fishes, mainly representatives of the order Ellimmichthyiformes (ThanMarchese et al., 2017). Recently, we launched a project to know the taxonomic identity of these Mexican fossils and explore their phylogenetic and biogeographical implications. We have identified the presence of three possible new species belonging to or related to the genus Armigatus; two of these are from the Albian deposits of Tlayúa quarry, Puebla, central Mexico, while the another one is from the Early Cenomanian strata exploited in the El Chango quarry, Chiapas, southeastern Mexico. The first of these species is described here, as $A$. carrenoae sp. nov., while the descriptive studies of the other two are in progress.

The discovery of $A$. carrenoae sp. nov. in the Albian deposits of the Tlayúa quarry represents the first record of Armigatus beyond the western realm of the Tethys Sea, in Europe, North Africa, and the Middle East, and the first record of this genus on the American continent. Moreover, A. carrenoae increases the temporal range of this genus up to the middle-late Albian (Figure 13). Although the interrelationships of the species of Armigatus are under discussion by different authors, the presence of Armigatus in the eastern and western extremes of the Tethys opens the question how this genus achieved such a wide distribution. One possibility is that Armigatus originated in the Middle East and migrated toward America through the epicontinental marine environments. Another possibility is precisely the opposite, in which these fishes appeared in America and subsequently invaded the littoral environments to reach the Middle East. Since $A$. carrenoae is the oldest record of the genus, the second of these possibilities seems more plausible; however, the identification of the other Mexi- can species of Armigatus and the development of comprehensive phylogenetic and biogeographic studies may still significantly alter our understanding of the origin and dispersal of Armigatus.

\section{CONCLUSIONS}

The present osteological description of Armigatus carrenoae sp. nov. provides conclusive evidence to recognize this Mexican species a representative of the superorder Clupeomorpha, order Ellimichthyiformes, family Armigatidae, and genus Armigatus. Thus, the discovery of $A$. carrenoae represents the first record of Armigatus in America and expands the geographical and temporal ranges of the genus up to America and the middle-late Albian, about 103 to $100.5 \mathrm{Ma}$ ago (Figure 13). The other species of this genus have been collected in Cenomanian-Campanian deposits of Europe, Northern Africa, and Lebanon.

Based on data of the nominal species of Armigatus already published (Forey et al., 2003; Vernygora and Murray, 2016, 2021, and Murray et al., 2016) and our observations of the predorsal scutes of fossil clupeomorphs, we here redefine the concept of "incomplete predorsal scute series." According to our proposed definition, this state is present in $A$. carrenoae, $A$. brevissimus, and $A$. alticorpus while a complete predorsal scute series is present in A. oligodentatus, A. namourensis, and $A$. dalmaticus. In the incomplete predorsal series, the scutes are few (probably no more than 10) and located in the posterior part of the predorsal edge of the trunk, far from the occiput, lie over the posterior three or four predorsal bones, and are preceded by numerous scales (Figures, 10, 12, 13). On the contrary, in the complete predorsal scute series, these scutes are more numerous and occupy a larger part of the predorsal edge of the trunk, are very close to the occiput anteriorly, lay above all predorsal bones, and are preceded by few or no scales.

Careful anatomical comparison with the other species of Armigatus led us to conclude that Armigatus carrenoae sp. nov. is the closest species to A. brevissimus morphologically. These two species share numerous features (Table 3 ), including the presence of predorsal scutes of subtriangular or heart shape that form a true incomplete predorsal series (Figures 10,12). Although Armigatus alticorpus also has an incomplete predorsal scute series, its scutes are rather subrectangular due to their extreme lateral expansion (Vernygora and Murray, 2021). 
The inclusion of Armigatus carrenoae sp. nov. into a phylogenetic study is desirable to assess the implications of its distinctive anatomy for the evolution of the Ellimmichthyiformes; however, for the moment the authors cannot complete this task because we are involved in the study of other Mexican fossils that potentially represent two new species of Armigatus (Alvarado-Ortega, 2014; Alvarado-Ortega and Melgarejo-Damián, 2017; Than-Marchese et al., 2017). Before performing a phylogenetic study, we want to have a complete picture of the morphological diversity of Armigatus in Mexico.

\section{ACKNOWLEDGEMENTS}

We are deeply indebted to Aranguthy family and their quarry workers, who are the real discov- erers of the paleontological treasures of the Tlayúa Lagesrtätte. Dr. K.M. Cantalice and Mr. J.M. Contreras made all the photographic work to illustrate this manuscript. This work was significantly improved with the observations and suggestions kindly provided by Drs. O. Vernygora, A. Murray, J. Divay, O. Kovalchuk, and G. Marramà. We thank the kindly help by Dr. Timothy Gregory. The Universidad Nacional Autónoma de México provided us with the financial support throughout the subventions DGAPA-PAPIIT IN110920 and IN209017. Additional support was provided by CONACyTMexico throughout the Graduate scholarships given to MDMP (grant 251071/215503) and BATM (grant 16676).

\section{REFERENCES}

Alvarado-Ortega, J. 1999. The fossil conservation on the Tlayúa quarries, Tepexi de Rodríguez, Puebla, Mexico. 33rd Annual Meeting of the Geological Society of America, South-Central Section. Lubbock, Texas, U.S.A., Geological Society of America, 31(1):A1.

Alvarado-Ortega, J. 2004. Description and relationships of a new ichthyodectiform fish from the Tlayúa Formation, Puebla, Mexico. Journal of Vertebrate Paleontology, 24:802-813. https://doi.org/10.1671/0272-4634(2004)024[0802:DAROAN]2.0.CO;2

Alvarado-Ortega, J. 2005. Sistemática de los peces Ichthyodectiformes de la Cantera Tlayúa, Puebla, México. Unpublished PhD Thesis, Facultad de Ciencias, Universidad Nacional Autónoma de México, México.

Alvarado-Ortega, J. 2014. Ancient herring from the Tlayúa Quarry (Cretaceous, Albian) near Tepexi de Rodíguez, Puebla State, central Mexico, closing the gap in the early diversification of Clupeomorpha. Cretaceous Research, 50:171-186. https://doi.org/10.1016/j.cretres.2014.02.022

Alvarado-Ortega, J., Espinosa-Arrubarrena, L., Blanco, A., Vega, F.J., Benammi, M., and Briggs, D.E. 2007. Exceptional preservation of soft tissues in Cretaceous fishes from the Tlayua Quarry, central Mexico. Palaios, 22:682-685. https://doi.org/10.2110/palo.2006.p06-059r

Alvarado-Ortega, J., González-Rodríguez, K.A., Blanco-Piñón, A., Espinosa-Arrubarrena, L., and Ovalles-Damián, E. 2006. Mesozoic osteichthyans of Mexico, p. 169-207. In Vega, F.J., Nyborg, T.G., Perillita, M.C., Montellano-Ballesteros, M., Cevallos-Ferriz S.R.S., and QuirozBarroso S.A. (eds.), Studies on Mexican Paleontology, Topics on Geobiology, 24. Springer, Dordrecht, the Netherlands.

Alvarado-Ortega, J. and Melgarejo-Damián, M.P. 2017. Paraclupea seilacheri sp. nov., a double armored herring (Clupeomorpha, Ellimmichthyiformes) from the Albian limestones of Tlayúa quarry, Puebla, Mexico. Revista Mexicana de Ciencias Geológicas, 34:234-249. https://doi.org/10.22201/cgeo.20072902e.2017.3.528

Alvarado-Ortega, J. and Ovalles-Damián, E. 2008. Triplomystus applegatei, sp. nov. (Teleostei: Ellimmichthyiformes), a rare "triple armored herring" from El Espinal Quarry (Early Cretaceous), Chiapas, southeastern Mexico. Journal of Vertebrate Paleontology, 28:53-60. https://doi.org/10.1671/0272-4634(2008)28[53:TASNTE]2.0.CO;2

Alvarado-Ortega, J., Ovalles-Damián, E., and Arratia, G. 2008. A review of the interrelationships of the order Ellimmichthyiformes (Teleostei: Clupeomorpha), p. 257-278. In Arratia, G., Schultze, H.-P., and Wilson, M.V.H. (eds.), Mesozoic fishes 4 -Homology and phylogeny. München, Verlag Dr. Friedrich Pfeil. 
Applegate, S.P. 1988. A new genus and species of a holostean belonging to the family Ophiopsidae, Teoichthys kallistos, from the Cretaceous near Tepexi de Rodríguez, Puebla. Instituto de Geología, Revista, 7:200-205.

Applegate, S.P. 1996. An overview of the Cretaceous fishes of the quarries near Tepexi de Rodríguez, Puebla, México, p. 529-538. In Arratia, G. and Viohl, G., (eds.), Mesozoic Fishes - Systematics and Paleoecology. München, Verlag Dr. Friedrich Pfeil.

Applegate, S.P., Buitrón, B.E., and López-Neri, P. 1982. La Cantera Tlayúa en la región de Tepexi de Rodríguez, Puebla, el Solnhofen de México. In Resúmenes VI Congreso Nacional de Zoología. Universidad Autónoma de Sinaloa, México (not paginated, ed. unknown).

Applegate, S.P., Buitrón-Sánchez, B.E., Solís-Marín, F.A., and Laguarda-Figueras, A. 2009. Two Lower Cretaceous (Albian) fossil holothurians (Echinodermata) from Tepexi de Rodríguez, Puebla, Mexico. Proceedings of the Biological Society of Washington, 122:91-102. https://doi.org/10.2988/07-41.1

Applegate, S.P. and Espinosa-Arrubarrena, L. 1982. Lithographic limestone-like deposits in Tepexi de Rodríguez, Puebla, Mexico. Fieldtrip guidebook. 42th Annual Meeting, Society of Vertebrate Paleontology, Mexico City. Universidad Nacional Autónoma de México, Instituto de Geología.

Applegate, S.P., Espinosa-Arrubarrena, L., Alvarado-Ortega, J., and Benammi, M. 2006. Revision of recent investigations in the Tlayúa quarry, p. 276-304. In Vega, F.J., Nyborg, T.G., Perrilliat, M.-C., Montellano-Ballesteros, M., Cevallos-Ferriz, S.R.S., and Quiroz-Barroso, S.A. (eds.), Studies on Mexican Paleontology, Topics on Geobiology 24. Springer, Dordrecht, The Netherlands.

Arratia, G. 1997. Basal teleosts and teleostean phylogeny. Palaeolchthyologica, 7:1-168.

Bannikov, A.F. 2015. A new genus for the Cenomanian ellimmichthyiform fishes from Lebanon and Mexico. Bollettino della Societa Paleontologica Italiana, 54:211-218.

Bannikov, A.F. and Bacchia, F. 2000. A remarkable clupeomorph fish (Pisces, Teleostei) from a new Upper Cretaceous marine locality in Lebanon. Senckenbergiana lethaea, 80:3-11.

Bannikov, A.F. and Sorbini, C. 2000. Preliminary note on a lower Paleocene fish fauna from Trebiciano (Trieste-North-Eastern Italy). Atti del Museo civico di storia naturale di Trieste, 48:15-30.

Benammi, M., Alvarado-Ortega, J., and Urrutia-Fucugauchi, J. 2006. Magnetostratigraphy of the Lower Cretaceous strata in Tlayúa Quarry, Tepexi de Rodríguez, State of Puebla, Mexico. Earth, Planets and Space, 58:1295-1302. https://doi.org/10.1186/BF03352624

Blainville, H.D. 1818. Nouveau dictionnaire d'histoire naturelle. Poissons fossiles. Deterville, Paris.

Boukhalfa, K., Wu, F., Ben Ali, W., and Fang, G. 2019. A new paraclupeid fish (Clupeomorpha: Ellimmichthyiformes) from the Lower Cretaceous Sidi Aich Formation of southern Tunisia: phylogenetic and paleobiogeographic implications. Journal of Vertebrate Paleontology, 38:e1529675. https://doi.org/10.1080/02724634.2018.1529675

Brito, M.P., Villalobos, E., and Alvarado-Ortega, J. 2019. A new early cretaceous guitarfish (Chondrichthyes, Batoidea) from the Tlayúa Formation, Puebla, Mexico. Journal of South American Earth Sciences, 90:155-161. https://doi.org/10.1016/j.jsames.2018.12.005

Buitrón, B.E. and Malpica-Cruz, R. 1987. Tepexi de Rodríguez, Puebla, una localidad fosilífera de México, Field Trip Guidebook. Distrito Federal, México, Sociedad Mexicana de Paleontología.

Cantú-Chapa, A. 1987. Las amonitas del Albiano Superior de Tepexi de Rodríguez, Puebla. Sociedad Mexicana de Paleontología, Revista, 1:159-160.

Casier, E. 1965. Poissons fossiles de la serie du Kwango (Congo). Annales Musee Royal de L'Afrique Centrale, Sciences Geologiques, Tervuren, 50:1-64.

Chang, M.-M. and Grande, L. 1997. Redescription of Paraclupea chetunguensis, an early Clupeomorph from the Lower Cretaceous of Southeastern China. Fieldiana, Geology, 37:119.

Chang, M.-M. and Maisey, J.G. 2003. Redescription of Ellimma branneri and Diplomystus shengliensis, and relationships of some basal Clupeomorphs. American Museum Novitates, 3404:1-35.

Cope, E.D. 1877. A contribution to the knowledge of the ichthyological fauna of the Green River Shales. Bulletin of the United States Geological and Geographical Survey, 3:807-819.

Cope, E.D. 1886. A contribution to the vertebrate paleontology of Brazil. Proceedings of the American Philosophical Society, 23:1-21. 
Datovo, A. and Vari, R.P. 2013. The jaw adductor muscle complex in teleostean fishes: evolution, homologies and revised nomenclature (Osteichthyes: Actinopterygii). PLOS One, 8(4):e60846. https://doi.org/10.1371/journal.pone.0060846

Di Dario, F. 2004. Homology between the recessus lateralis and cephalic sensory canals, with the proposition of additional synapomorphies for the Clupeiformes and the Clupeoidei. Zoological Journal of the Linnean Society, 141:257-270. https://doi.org/10.1111/j.1096-3642.2004.00122.x

Espinosa-Arrubarrena, L. and Applegate, S.P. 1996. A possible model for the paleoecology of the vertebrate bearing beds in the Tlayúa quarries, near Tepexi de Rodríguez, Puebla, Mexico, p. 539-550. In Arratia, G. and Viohl, G. (eds.), Mesozoic Fishes -Systematics and Paleoecology-. München, Verlag Dr. Friedrich Pfeil.

Eastman, C.R. 1912. Tertiary fish-remains from Spanish Guinea in West Africa. Annals of Carnegie Museum, 8:370-378.

Feldmann, R.M., Vega, F.J., Applegate, S.P., and Bishop, G.A. 1998. Early Cretaceous arthropods from the Tlayúa Formation at Tepexi de Rodríguez, Puebla, Mexico. Journal of Paleontology, 72:79-90. http://www.jstor.org/stable/1306680

Figueiredo, F.J. and Ribeiro, D.R.M. 2016. Relationships of †Codoichthys carnavalii Santos, 1994 (Teleostei, Clupeomorpha, †Ellimmichthyiformes) from the Late Aptian of São LuísGrajaú Basin, NE Brazil. Anais da Academia Brasileira de Ciências, 88:1277-1307. https://doi.org/10.1590/0001-3765201620150495

Figueiredo, F.J. and Ribeiro, D.R.M. 2017. Reassessment and relationships of †Scutatuspinosus itapagipensis (Teleostei, Clupeomorpha, †Ellimmichthyiformes) from the Neocomian of Recôncavo Basin, Northeastern Brazil. Anais da Academia Brasileira de Ciências, 89:799823. https://doi.org/10.1590/0001-3765201620160310

Forey, P.L. 1973. A primitive clupeomorph fish from the Middle Cenomanian of Hakel, Lebanon. Canadian Journal of Earth Sciences, 10:1302-1318. https://doi.org/10.1139/e73-114

Forey, P.L. 1975. A fossil clupeomorph fish from the Albian of the Northwest Territories of Canada, with notes on cladistic relationships of clupeomorphs. Journal of Zoology, 175:151177. https://doi.org/10.1111/j.1469-7998.1975.tb01394.x

Forey, P.L. 2004. A three-dimensional skull of a primitive clupeomorph from the Cenomanian English Chalk, and implications for the evolution of the clupeomorph acusticolateralis system, p. 405-427. In Arratia, G. and Tintori, A. (eds.), Mesozoic Fishes 3 - Systematics, Paleoenvironments and Biodiversity -. München, Verlag Dr. Friedrich Pfeil.

Forey, P.L., Yi, L., Patterson, C., and Davies, E. 2003. Fossil fishes from the Cenomanian (Upper Cretaceous) of Namoura, Lebanon. Journal of Systematic Palaeontology, 1:227-330. https://doi.org/10.1017/S147720190300107X

Gaudant, M. and Gaudant, J. 1971. Une nouvelle espece de Diplomystus (Poisson teléostéen) dans le Crétacé supérieur du Sud Tunisien. Bulletin de la Société Géologique de France, 13(7):156-159.

González-Cruz, M.T. 2015. Palinología de la Formación Tlayúa (Cretácico Temprano), Tepexi de Rodríguez, Puebla, México. Unpublished Bachelor Thesis, Facultad de Estudios Superiores Iztacala, Universidad Nacional Autónoma de México. Distrito Federal, México.

González-Rodríguez, K., Applegate, S.P., and Espinosa-Arrubarrena, L. 2004. A New World macrosemiid (Pisces: Neopterygii, Halecostomi) from the Albian of Mexico. Journal of Vertebrate Paleontology, 24:281-289. https://doi.org/10.1671/1862

González-Rodríguez, K., Espinosa-Arrubarrena, L., and Gonzalez-Barba, G. 2013. An overview of the Mexican fossil fish record, p. 9-34. In Arratia, G., Schultze, H.-P., and Wilson, M.V. (eds.), Mesozoic Fishes 5 - Global Diversity and Evolution. München, Verlag Dr. Friedrich Pfeil.

Grande, L. 1982. A revision of the fossil genus Diplomystus, with comments on the interrelationships of clupeomorph fishes. American Museum Novitates, 2728:1-34.

Grande, L. 1985. Recent and fossil clupeomorph fishes with materials for revision of the subgroups of Clupeoids. Bulletin of the American Museum of Natural History, 181:231-372.

Greenwood, P.H., Rosen, D.E., Weitzman, H., and Myers, G.S. 1966. Phyletic studies of teleostean fishes, with a provisional classification of living forms. Bulletin of the American Museum of Natural History, 131:339-455. 
Hay, M.J., Cumbaa, S.L., Murray, A.M., and Plint, A.G. 2007. A new paraclupeid fish (Clupeomorpha, Ellimmichthyiformes) from a muddy marine pro-delta environment: middle Cenomanian Dunvegan Formation, Alberta, Canada. Canadian Journal of Earth Sciences, 44:775-790. https://doi.org/10.1139/e07-002

Hermus, C.R., and Wilson, M.V.H. 2001. A new species of Erichalcis from Arctic Canada, with a revised diagnosis of the genus, p. 41. In Arratia, G. and Tintori, A. (eds.), III International Meeting on Mesozoic Fishes Systematics, Paleoenvironments and Biodiversity, Abstract Book, Serpiano-Monte San Giorgio, Milan University,

Hermus, C.R., Wilson, M.V.H., and Macrae, A. 2004. A new species of the Cretaceous teleostean fish Erichalcis from Arctic Canada, with a revised diagnosis of the genus, p. 449461. In Arratia, G. and Tintori, A (eds.), Mesozoic Fishes 3 -Systematics, Paleoenvironments and Biodiversity-. München, Verlag Dr. Friedrich Pfeil.

Jordan, D.S. 1910. Description of a collection of fossil fishes from the bituminous shales at Riacho Doce, State of Alagôas, Brazil. Annals of Carnegie Museum, 7:23-34.

Kashiyama, Y., Fastovsky, D.E., Rutherford, S., King, J., and Montellano, M. 2004. Genesis of a locality of exceptional fossil preservation: paleoenvironments of Tepexi de Rodríguez (midCretaceous, Puebla, México). Cretaceous Research, 25:153-177. https://doi.org/10.1016/j.cretres.2003.11.002

Khalloufi, B., Zaragüeta-Bagils, R., and Lelièvre, H. 2010. Rhombichthys intoccabilis, gen. et sp. nov. (Ellimmichthyiformes, Clupeomorpha, Teleostei), from the Cenomanian (Upper Cretaceous) of Ein Yabrud, Middle East: anatomical description and phylogenetic implications. Journal of Vertebrate Paleontology, 30:57-67. https://doi.org/10.1080/02724630903409089

Machado, G.P., Alvarado-Ortega, J., Machado, L.P., and Brito, P.M. 2013. Teoichthys brevipina, sp. nov., a new ophiopsid fish (Halecomorphi, lonoscopiformes) from the Lower Cretaceous Tlayúa Formation, Central Mexico. Journal of Vertebrate Paleontology, 33:482-487. https://doi.org/10.1080/02724634.2013.729962

Malabarba, M.C., Do Carmo, D.A., Gómez-Pérez, I., and de Queiroz-Neto, J.V. 2004. A new clupeomorph fish from the Cretaceous Maceió Formation, Alagoas Basin, NE Brazil. Neues Jahrbuch für Geologie und Paläontologie-Abhandlungen, 233:255-274.

Marramà, G., Bannikov, A.F., Kriwet, J., and Carnevale, G. 2019. An Eocene paraclupeid fish (Teleostei, Ellimmichthyiformes) from Bolca, Italy: the youngest marine record of doublearmored herrings. Papers in Palaeontology, 5:83-98. https://doi.org/10.1002/spp2.1230

Marramà, G. and Carnevale, G. 2017. The relationships of Gasteroclupea branisai Signeux, 1964, a freshwater double-armored herring (Clupeomorpha, Ellimmichthyiformes) from the Late Cretaceous-Paleocene of South America. Historical Biology, 29:904-917. https://doi.org/10.1080/08912963.2016.1262855

Martill, D.M. 1989. A new Solenhofen in Mexico. Geology Today, 5:25-28.

Martin-Medrano, L., Thuy, B., and García-Barrera, P. 2009. New Albian (Early Cretaceous) ophiuroids from the Tlayúa Quarry, Puebla, Mexico. Palaeontology, 52:83-94.

Melgarejo-Damián, M.P. 2011. Análisis cuantitativo multivariado de los peces elimictiformes de la Cantera Tlayúa (Cretácico: Albiano), Puebla, México. Unpublished Master Thesis, Posgrado en Ciencias Biológicas, Instituto de Geología, Universidad Nacional Autónoma de México, Distrito Federal, México.

Melgarejo-Damián M.P. and Alvarado-Ortega, J. 2009. Los peces Ellimmichthyiformes (Teleostei, Clupeomorpha) de la Cantera Tlayúa, p. 44. In (ed. unknown) Libro de Resúmenes, XI Congreso Nacional de Paleontología. Juriquilla, Querétaro, Centro de Geociencias, Campus-UNAM Juriquilla.

Melgarejo-Damián M.P. and Alvarado-Ortega, J. 2010. A multivariate approach on the Ellimmichthyiformes of Tlayúa Quarry (Lower Cretaceous), Tepexi de Rodríguez, Puebla, México, p. 69. In González-Rodríguez K.A. and Arratia, G. (eds.), Fifth International Meeting on Mesozoic fishes - Global Diversity and evolution, Abstract Book and Field Guides. Coahuila, México. Pachuca, México, Universidad Autónoma del Estado Hidalgo.

Melgarejo-Damián M.P. and Alvarado Ortega, J. 2013. Un enfoque cuantitativo multivariado em los peces elimictiformes de La Cantera Tlayúa, p. 64. In Reynoso, V.H., Oseguera, B., and Flores-Mejía, P. (eds.), Programa y Resúmenes del VIII Congreso Latinoamericano de Paleontología y XIII Congreso Nacional de Paleontología. Museo Dugés, Guanajuato, México, Universidad de Guanajuato. 
Murray, A.M. and Wilson, M.V. 2011. A new species of Sorbinichthys (Teleostei: Clupeomorpha: Ellimmichthyiformes) from the Late Cretaceous of Morocco. Canadian Journal of Earth Sciences, 48:1-9. https://doi.org/10.1139/E10-084

Murray, A.M., and Wilson, M.V. 2013. Two new paraclupeid fishes (Clupeomorpha: Ellimmichthyiformes) from the Upper Cretaceous of Morocco, p. 267-290. In Arratia, G., Schultze, H.-P., Wilson, M.V.H. (eds.), Mesozoic fishes 5 - Global Diversity and Evolution. München, Verlag Dr. Friedrich Pfeil.

Murray, A.M., Vernygora, O., Japundžlć, S., Radovčić, J., Wilson, M.V.H., Bardack, D., and Grande, T. 2016. Relationships of the species of Armigatus (Clupeomorpha, Ellimmichthyiformes) and the description of a new species from the Cretaceous of Dalmatia, Croatia. Journal of Vertebrate Paleontology, 36:e1226851. https://doi.org/10.1080/02724634.2017.1226851

Newbrey, M.G., Murray, A.M., Brinkman, D.B., Wilson, M.V.H., and Newman, A.G. 2010. A new articulated freshwater fish (Clupeomorpha, Ellimmichthyiformes) from the Late Cretaceous Horseshoe Canyon Formation, Alberta, Canada. Canadian Journal of Earth Sciences, 47:1183-1196. https://doi.org/10.1139/E10-041

Osse, J.W.M. 1969. Functional morphology of the head of the perch (Perca fluviatilis L.): an electromyographic study. Netherlands Journal of Zoology, 19:289-392.

Pantoja-Alor, J. 1992. Geología y paleoambiente de la Cantera Tlayúa, Tepexi de Rodríguez, Estado de Puebla. Instituto de Geología, Revista, 9:156-169.

Patterson, C. and Rosen, D.E. 1977. A review of ichthyodectiform and other Mesozoic teleost fishes, and the theory and practice of classifying fossils. Bulletin of the American Museum of Natural History, 158:281-172.

Pictet, F.J. 1850. Description de quelques poissons fossiles du Mont Liban. Genève, J.G. Fick.

Polck, M.A.R., Gallo, V., Figueiredo, F.J., Viana, S.M., Santos, V.S.S., Quiroz Neto, J.V.Q., and Jahnert, R.J. 2020. †Ellimma longipectoralis sp. nov. (Teleostei: Clupeomorpha:†Ellimmichthyiformes) from the Aptian of the Santos Basin, southeastern Brazil. Journal of South American Earth Sciences, 98:102318. https://doi.org/10.1016/ j.jsames.2019.102318

Poyato-Ariza, F.J., López-Horgue, M.A., and García-Garmilla, F. 2000. A new early Cretaceous clupeomorph fish from the Arratia Valley, Basque Country, Spain. Cretaceous Research, 21:571-585. https://doi.org/10.1006/cres.2000.0212

Reynoso, V.H. 1998. Acatlántida y el origen insular de la fauna terrestre de Tlayúa. Avances en Investigación: Paleontología de Vertebrados. Instituto de Investigaciones en Ciencias de la Tierra, Universidad Autónoma del Estado de Hidalgo, Publicación Especial, 1:4-11.

Santos, R.S. and Corréa, V.L.S. 1985. Contribuição ao conhecimento da paleoictiofaúnula do Cretáceo no Brasil, p. 169-194. In de Campos, A., Ferreira, C.S., Brito, I.M., and Viana, C.F. (eds.), Coletânea de Trabalhos Paleontológicos, Série Geologia 27. Rio de Janeiro, Brasil, Ministério de Minas e Energia-Departamento Nacional de Produção Mineral.

Seibertz, E. and Buitrón, B.E. 1987. Paleontología y estratigrafía de los Neohibolites del Albiano de Tepexi de Rodríguez, Estado de Puebla (Cretácico Medio, México). Sociedad Mexicana de Paleontología, Revista, 1:285-299.

Seibertz, E. and Spaeth, C. 2002. Cretaceous belemnites of Mexico III. The Albian Neo-and Mesohibolites of the "Mexican Solnhofen" Tepexi de Rodríguez (State of Puebla) and their biostratonomy (Lower Cretaceous). Neues Jahrbuch für Geologie und Paläontologie, Abhandlungen, 225:55-74. https://doi.org/10.1127/njgpa/225/2002/55

Signeux, J. 1951. Notes paléoichthyologiques. V. Diplomystus dubertreti, une nouvelle espèces du Sénonien du Liban. Bulletin du Muséum National d'Histoire Naturelle, 23:692-693.

Signeux J. 1964. Gasteroclupea branisai, clupéidé nouveau du Crétacé Supérieur de Bolivie. Bulletin du Muséum national d'histoire naturelle, 36:291-297.

Silva Santos, R. da. 1990. Clupeiformes e Gonorhynchiformes de Cretáceo Inferior (Aptiano) da Formação Cabo, Nordeste do Brasil. Anais da Academia Brasileira de Ciências, 62:261-268.

Silva Santos, R. da. 1994. Ictyofáunula da Formação Codó, Cretáceo Inferior, com a descrição de um Novo Táxon -Codoichthys carnavalii (Pisces-Teleostei). Anais da Academia Brasileira de Ciências, 66:131-143.

Sun, A.L. 1956. Paraclupea -a genus of double-armored herrings from Chekiang. Acta Palaeontologica Sinica, 4:413-418.

Taverne, L. 1997. Les clupéomorphes (Pisces, Teleostei) du Cénomanien (Crétacé) de Kipala (Kwango, Zaire): ostéologie et phylogénie. Belgium Journal of Zoology, 127:75-97. 
Than-Marchese, B.A., Alvarado-Ortega, J., Malgarejo-Damián, M.P., Solano-Templos, G., Matamoros, W., and Velázquez-Velázquez, E. 2017. ¿Son importantes los clupeomrfos fósiles de México para su filogenia?, p. 238. In (ed. unknown), XXIII Congreso Nacional de Zoología, Libro de resúmenes. Tuxtla Gutiérrez, Chiapas, Sociedad Mexicana de ZoologíaUniversidad de Ciencias y Artes de Chiapas.

Toombs, H.A. and Rixon, A.E. 1959. The use of acids in the preparation of vertebrate fossils. Curator, 2:304-312.

Uyeno, T. 1979. Early Cretaceous freshwater fishes from Northern Kyushu, Japan. 1. Description of two new species of the clupeid genus Diplomystus. Bulletin of the Kitakyushu Museum of Natural History, 1:11-24.

Vernygora, O. and Murray, A.M. 2016. A new species of Armigatus (Clupeomorpha, Ellimmichthyiformes) from the Late Cretaceous of Morocco, and its phylogenetic relationships. Journal of Vertebrate Paleontology, 36:e1031342. https://doi.org/10.1080/02724634.2015.1031342

Vernygora, O. and Murray, A.M. 2021. Morphological variation among the species of Armigatus (Teleostei, Clupeomorpha, Ellimmichthyiformes) and new material of Armigatus alticorpus from the Upper Cretaceous (Cenomanian) of Hakel, Lebanon. Cretaceous Research, 117:104601. https://doi.org/10.1016/j.cretres.2020.104601

Vernygora, O., Murray, A.M., and Wilson, M.V.H. 2016. A primitive clupeomorph from the Albian Loon River Formation (Northwest Territories, Canada). Canadian Journal of Earth Sciences, 53:331-342. https://doi.org/10.1139/cjes-2015-0172

Woodward, A.S. 1895. On two deep-bodied species of the Clupeoid genus Diplomystus. Journal of Natural History, 15(85):1-3.

Yabumoto, Y. 1994. Early Cretaceous freshwater fish fauna in Kyushu, Japan. Bulletin of the Kitakyushu Museum of Natural History, 13:107-254.

Zaragüeta-Bagils, R. 2002. Test morphologique et moleculaire des hypotheses de phylogénie des Clupeomorpha (Teleostei). Unpuplished PhD Thesis, Muséum National d'Histoire Naturale, Départament Historie de la Terre. Paris, France.

Zaragüeta-Bagils., R. 2004. Basal clupeomorphs and ellimmichthyiform phylogeny, p. 391-404. In: Arratia, and G., Tintori, A. (eds.), Mesozoic fishes 3 -Systematics, paleoenvironments and biodiversity-. München, Verlag Dr. Friedrich Pfeil.

Zhang, M.M., Zhou, J.J., and Qing, D.R. 1985. Tertiary fish fauna from coastal region of Bohai Sea. Academia Sinica Institute of Vertebrate Paleontology and Paleoanthropology Memoirs, 17:1-60. 